\title{
GEOTECHNICAL ASPECTS OF THE 22 FEBRUARY 2011 CHRISTCHURCH EARTHQUAKE
}

\author{
Misko Cubrinovski ${ }^{1}$, Brendon Bradley ${ }^{1}$, Liam Wotherspoon ${ }^{2}$, \\ Russell Green $^{3}$, Jonathan Bray ${ }^{4}$, Clint Wood ${ }^{5}$, Michael Pender ${ }^{2}$, \\ John Allen ${ }^{6}$, Aaron Bradshaw ${ }^{7}$, Glenn Rix $^{8}$, Merrick Taylor ${ }^{1}$, \\ Kelly Robinson ${ }^{1}$, Duncan Henderson ${ }^{1}$, Simona Giorgini ${ }^{1}$, \\ Kun Ma ${ }^{1}$, Anna Winkley ${ }^{1}$, Josh Zupan ${ }^{4}$, Thomas O'Rourke', \\ Greg DePascale $^{10}$, Donnald Wells ${ }^{11}$
}

\begin{abstract}
SUMMARY
The 22 February 2011, $\mathrm{M}_{\mathrm{w}}$ 6.2-6.3 Christchurch earthquake is the most costly earthquake to affect New Zealand, causing 181 fatalities and severely damaging thousands of residential and commercial buildings, and most of the city lifelines and infrastructure. This manuscript presents an overview of observed geotechnical aspects of this earthquake as well as some of the completed and on-going research investigations. A unique aspect, which is particularly emphasized, is the severity and spatial extent of liquefaction occurring in native soils. Overall, both the spatial extent and severity of liquefaction in the city was greater than in the preceding $4^{\text {th }}$ September 2010 Darfield earthquake, including numerous areas that liquefied in both events. Liquefaction and lateral spreading, variable over both large and short spatial scales, affected commercial structures in the Central Business District (CBD) in a variety of ways including: total and differential settlements and tilting; punching settlements of structures with shallow foundations; differential movements of components of complex structures; and interaction of adjacent structures via common foundation soils. Liquefaction was most severe in residential areas located to the east of the CBD as a result of stronger ground shaking due to the proximity to the causative fault, a high water table approximately $1 \mathrm{~m}$ from the surface, and soils with composition and states of high susceptibility and potential for liquefaction. Total and differential settlements, and lateral movements, due to liquefaction and lateral spreading is estimated to have severely compromised 15,000 residential structures, the majority of which otherwise sustained only minor to moderate damage directly due to inertial loading from ground shaking. Liquefaction also had a profound effect on lifelines and other infrastructure, particularly bridge structures, and underground services. Minor damage was also observed at flood stop banks to the north of the city, which were more severely impacted in the $4^{\text {th }}$ September 2010 Darfield earthquake. Due to the large high-frequency ground motion in the Port hills numerous rock falls and landslides also occurred, resulting in several fatalities and rendering some residential areas uninhabitable.
\end{abstract}

\footnotetext{
${ }^{1}$ Department of Civil and Natural Resources Engineering, University of Canterbury, Christchurch, New Zealand

${ }^{2}$ Department of Civil and Environmental Engineering, University of Auckland, Auckland, New Zealand

${ }^{3}$ Department of Civil and Environmental Engineering, Virginia Tech, Blacksburg, VA, USA

${ }^{4}$ Department of Civil and Environmental Engineering, University of California Berkeley, Berkeley, CA, USA

${ }^{5}$ Department of Civil and Environmental Engineering, University of Arkansas, Fayetteville, AR, USA

${ }^{6}$ TRI Environmental, Inc., Austin, TX, USA

${ }^{7}$ Department of Civil and Environmental Engineering, University of Rhode Island, Kingston, RI, USA

${ }^{8}$ School of Civil and Environmental Engineering, Georgia Institute of Technology, Atlanta, GA, USA

${ }^{9}$ School of Civil and Environmental. Engineering., Cornell University., Ithaca, NY, USA

${ }^{10}$ Fugro/William Lettis and Associates, USA

${ }^{11}$ AMEC Geomatrix, Oakland, CA, USA
} 


\section{INTRODUCTION}

On 22 February 2011 at $12: 51 \mathrm{pm}$ local time, a moment magnitude $M_{w} 6.2-6.3$ earthquake occurred beneath the city of Christchurch, New Zealand, causing an unparalleled level of damage in the country's history, and the largest number of causalities since the 1931 Napier earthquake. Compared to the preceding $4^{\text {th }}$ September $2010 M_{w} 7.1$ Darfield earthquake [1], which occurred approximately $30 \mathrm{~km}$ to the west of Christchurch, the close proximity of the 22 February event led to ground motions of significantly higher amplitude in the densely populated regions of Christchurch.

A defining feature of the 22 February 2011 earthquake, as well as other events which have produced strong ground shaking in Christchurch city, was the large severity and spatial extent of liquefaction that occurred in native soils. The severity of strong motion also resulted in significant rock-falls in the Port Hills, substantial damage to commercial and residential structures; and damage to infrastructure networks in the eastern suburbs and central region of the city.

This manuscript provides an overview of observations made during post-event reconnaissance as well as some of the associated research activities related to geotechnical aspects of this event. Firstly, the tectonic and geologic setting of Christchurch is briefly discussed followed by presentation of the salient features of the densely recorded ground motions from the event. Observed liquefaction features are then presented in an overarching context and subsequently the impact of ground failure on the commercial structures, residential properties, and infrastructure is discussed. Finally, an overview of slope instability of the Port Hills is given.

\section{REGIONAL TECTONICS}

New Zealand resides on the boundary of the Pacific and Australian plates and its active tectonics are dominated by [2]: (i) oblique subduction along the Hikurangi trough in the North Island; (ii) oblique subduction along the Puysegur trench in the south west of the South Island; and (iii) oblique, right lateral slip within the axial tectonic belt. There are numerous identified faults in the Southern Alps and eastern foothills [3] and several significant earthquakes (i.e. $M_{w}>6$ ) have occurred in this region in the past 150 years, most notably the $M_{w} 7.1$ Darfield earthquake on 04/09/2010 [1]. The $M_{w} 6.2-6.3$ Christchurch earthquake occurred at $12: 51 \mathrm{pm}$ on Tuesday 22/02/2011 beneath Christchurch and represents the most significant earthquake in the unfolding seismic sequence in the Canterbury region since the 04/09/2010 Darfield earthquake. The $M_{w} 6.2-6.3$ event occurred on a previously unrecognised south-east dipping blind fault, which trends north-east to south-west, with a reverse-oblique slip orientation $[4,5]$ and is located to the south-east of the city centre (Figure 1).

\section{GEOLOGY OF THE CHRISTCHURCH AREA}

Christchurch is located on the Canterbury Plains, a fan deposit resulting from the numerous rivers flowing eastward from the foothills of the Southern Alps [6]. In the vicinity of Christchurch, the Canterbury Plains are comprised of a complex sequence of gravels inter-bedded with silt, clay, peat, and shelly sands. The fine sediments form aquicludes and aquitards between the gravel aquifers, and with the nearby coastline to the east, result in the majority of Christchurch having a water table less than $3 \mathrm{~m}$ depth, with most of the area to the east of the central business district having a water table of about $1 \mathrm{~m}$ from the surface [6]. The postglacial 'Christchurch formation' created by estuarine, lagoonal, dune, and coastal swamp deposits (containing gravel, sand, silt, clay, shell and peat) is the predominant surface geology layer in the eastern Christchurch area which outcrops up to $11 \mathrm{~km}$ west of the coast and has a thickness of approximately $40 \mathrm{~m}$ at the present coastline [6]. At the southeast edge of Christchurch lies the extinct Banks Peninsula volcanic complex.

\section{OBSERVED GROUND MOTIONS}

Here a summary of the observed ground motions is given to provide context for the observed response of geotechnical structures in the latter sections. Further details can be found in, for example, Bradley and Cubrinovski (this issue), among others.

Table 1 summarizes the intensity of ground motions in the greater Christchurch region that were recorded within a source-to-site distance of $R_{\text {rup }}=20 \mathrm{~km}$ of the causative fault, in terms of the geometric mean horizontal peak ground acceleration $(P G A)$ and vertical peak ground acceleration, $P G A_{v}$. Figure 1 illustrates the spatial distribution of faultnormal acceleration time histories recorded at the aforementioned strong motion stations. The inferred surface projection of the causative fault [4] is also shown. It can be seen that the close proximity of the fault to the city led to large ground motions in the horizontal and vertical directions, with a horizontal $P G A$ of $1.41 \mathrm{~g}$ recorded at Heathcote Valley, and seven ground motion records have horizontal $P G A$ values greater than $0.4 \mathrm{~g}$. In the central business district (CBD), $P G A$ values range from $0.37-0.52 \mathrm{~g}$, approximately 1.6 times higher seismic demand than that of the $4^{\text {th }}$ September 2010 earthquake in terms of liquefaction triggering [7].

Table 1: Summary of observed ground motions at strong motion stations.

\begin{tabular}{ccccc} 
Station Name & Code & $R_{\text {rup }}(\mathrm{km})$ & $P G A(\mathrm{~g})$ & $P G A_{v}(\mathrm{~g})$ \\
\hline Canterbury Aeroclub & CACS & 12.8 & 0.21 & 0.19 \\
$\begin{array}{c}\text { Christchurch Botanic } \\
\text { Gardens }\end{array}$ & CBGS & 4.7 & 0.50 & 0.35 \\
$\begin{array}{c}\text { Christchurch Cathedral } \\
\text { College }\end{array}$ & CCCC & 2.8 & 0.43 & 0.79 \\
$\begin{array}{c}\text { Christchurch Hospital } \\
\text { Cashmere High School }\end{array}$ & CHHC & 3.8 & 0.37 & 0.62 \\
Hulverstone Dr Pumping & 1.4 & 0.37 & 0.85 \\
Station & HPSC & 3.9 & 0.22 & 1.03 \\
Heathcote Valley School & HVSC & 4.0 & 1.41 & 2.21 \\
Kaipoi North School & KPOC & 17.4 & 0.20 & 0.06 \\
Lincon School & LINC & 13.6 & 0.12 & 0.09 \\
Lyttelton Port & LPCC & 7.1 & 0.92 & 0.51 \\
\hline
\end{tabular}

\begin{tabular}{ccccc} 
Station Name & Code & $R_{\text {rup }}(\mathrm{km})$ & $P G A(\mathrm{~g})$ & $P$ \\
\hline $\begin{array}{c}\text { Lyttelton Port Naval Point } \\
\text { North New Brighton }\end{array}$ & LPOC & 6.6 & 0.34 & 0.39 \\
$\begin{array}{c}\text { School } \\
\text { NNBS }\end{array}$ & 3.8 & 0.67 & 0.80 \\
Papanui High School & PPHS & 8.6 & 0.21 & 0.21 \\
Pages Rd Pumping Station & PRPC & 2.5 & 0.63 & 1.88 \\
Christchurch Resthaven & REHS & 4.7 & 0.52 & 0.51 \\
Riccarton High School & RHSC & 6.5 & 0.28 & 0.19 \\
Rolleston School & ROLC & 19.6 & 0.18 & 0.08 \\
Shirley Library & SHLC & 5.1 & 0.33 & 0.49 \\
Styx Mill Transfer Station & SMTC & 10.8 & 0.16 & 0.17 \\
Templeton School & TPLC & 12.5 & 0.11 & 0.16 \\
\hline
\end{tabular}




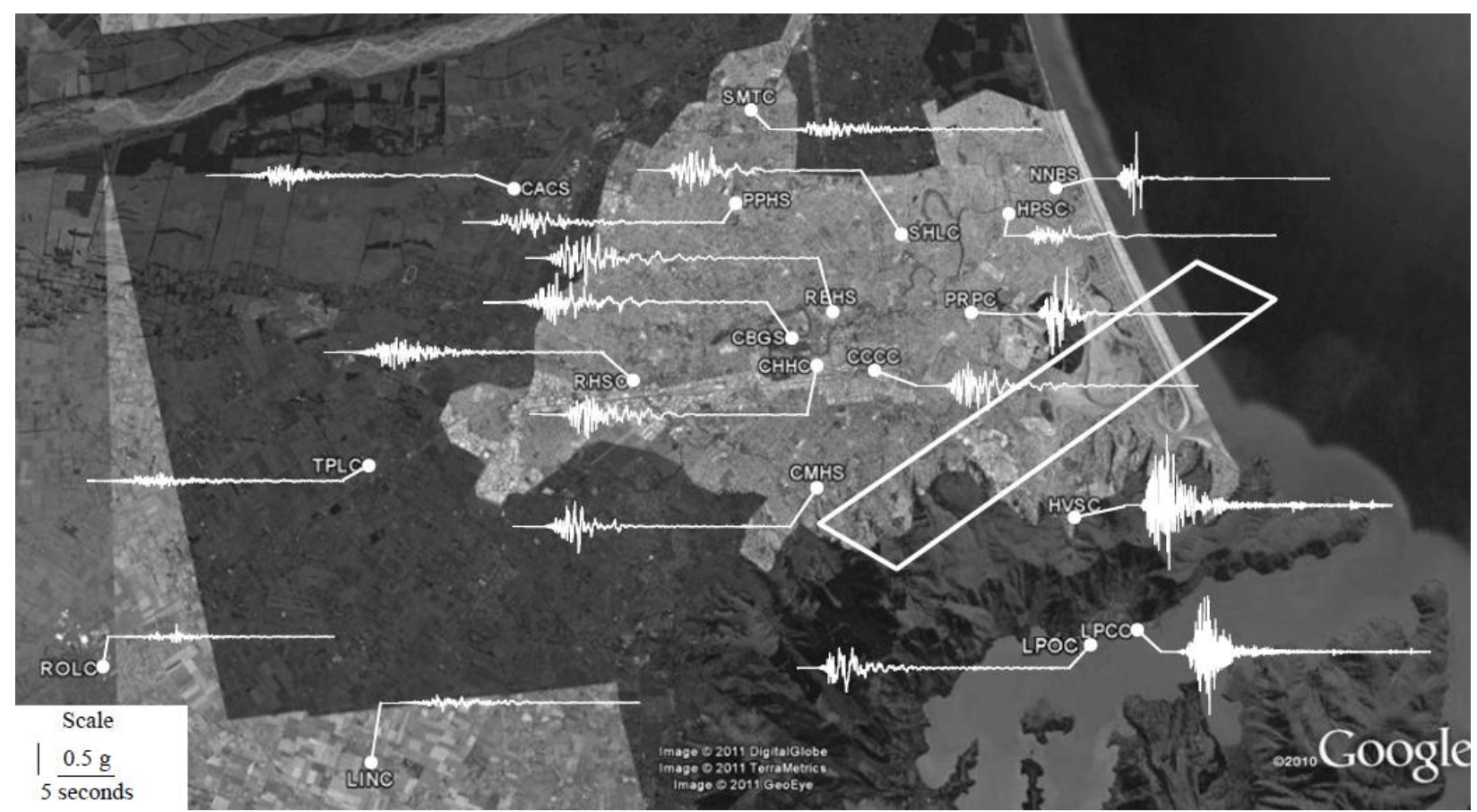

Figure 1: Observed fault-normal horizontal acceleration time histories at various locations in the Christchurch region from the 22 February earthquake with reference to the inferred surface projection of the causative fault which dips to the south-east (Bradley and Cubrinovski, this issue).

\section{Importance of nonlinear soil response}

An illustration of the significant effects of non-linear soil response under strong ground motion can be seen by comparing the ground motions observed on rock and soil sites at Lyttelton Port (LPCC and LPOC, respectively). In addition to a comparison of the acceleration time histories in Figure 1, Figure 2 illustrates the pseudo-acceleration response spectra of the geometric mean horizontal and vertical ground motion components at the two sites. It can be seen that, compared to LPCC, the observed ground motion at the LPOC soil site has significantly lower amplitude of high frequency content, longer predominant period, and larger significant duration in the horizontal direction. In contrast, it can be seen that there is relatively little difference between the vertical ground motions at the two sites, because of the relatively large compressive stiffness of the sites, with peak vertical accelerations of 0.51 and $0.39 \mathrm{~g}$, respectively.

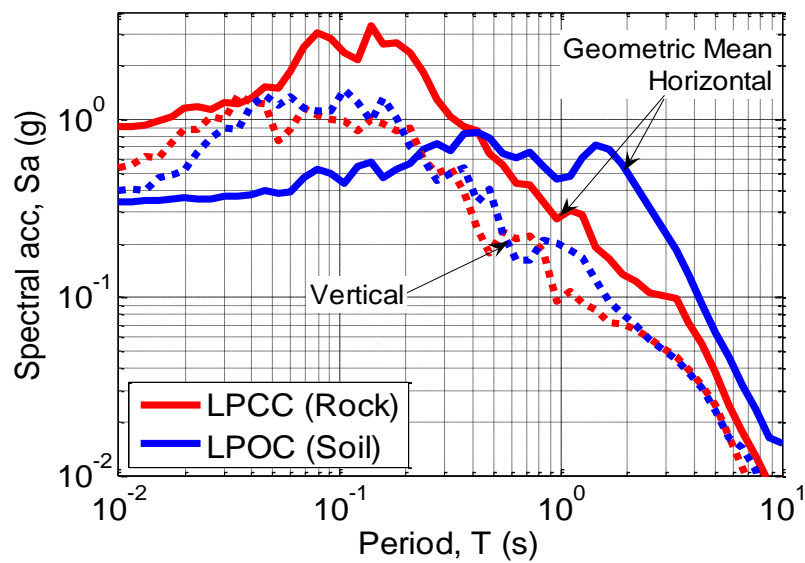

Figure 2: Comparison of geometric mean horizontal and vertical response spectra observed at two nearby strong motion stations in Lyttelton, one on outcropping rock $(\mathrm{LPCC})$, the other on soil (LPOC) [8].

\section{Liquefaction observed in recorded ground motions}

As elaborated upon subsequently, one of the major causes of damage in the $M_{w} 6.2-6.3$ Christchurch earthquake resulted from the widespread and very severe liquefaction in residential, commercial and industrial areas. The horizontal components of acceleration depicted in Figure 1 show evidence of liquefaction in the central business district and eastern suburbs which are located in the near-source region beyond the up-dip projection of the fault plane. For example, in the central business district (e.g. CBGS), Cashmere (CMHS) and Shirley (SHLC), evidence of liquefaction is inferred from the manifested reduction in high frequency content of ground motion following several seconds of S wave arrivals, and the subsequent acceleration 'spikes', characteristic of strain hardening deformation during cyclic mobility.

\section{Sedimentary basin generated surface waves and near-} source directivity

Christchurch is located on a sedimentary fan deposit with the volcanic rock of Banks Peninsula located to the south east. Because of the location of the causative fault to the south of the city, and the increasing depth of the volcanic rock-basin interface moving in the north-west direction, it is likely that seismic waves emanating from the rupture entered the sedimentary basin through its thickening edge, leading to a waveguide effect in which surface waves propagate across the basin resulting in enhanced long period ground motion amplitudes and shaking duration. Because of the near-source location of the city to the causative fault, directivity effects associated with the rupture propagation were important features in the ground motions observed at specific locations. Directivity effects appear to be most significant in the eastern suburbs of the city, due to its proximity to the rupture asperity. For the central business district, near-source directivity effects are inferred as of secondary importance to the basin-generated surface waves at long vibration periods. 

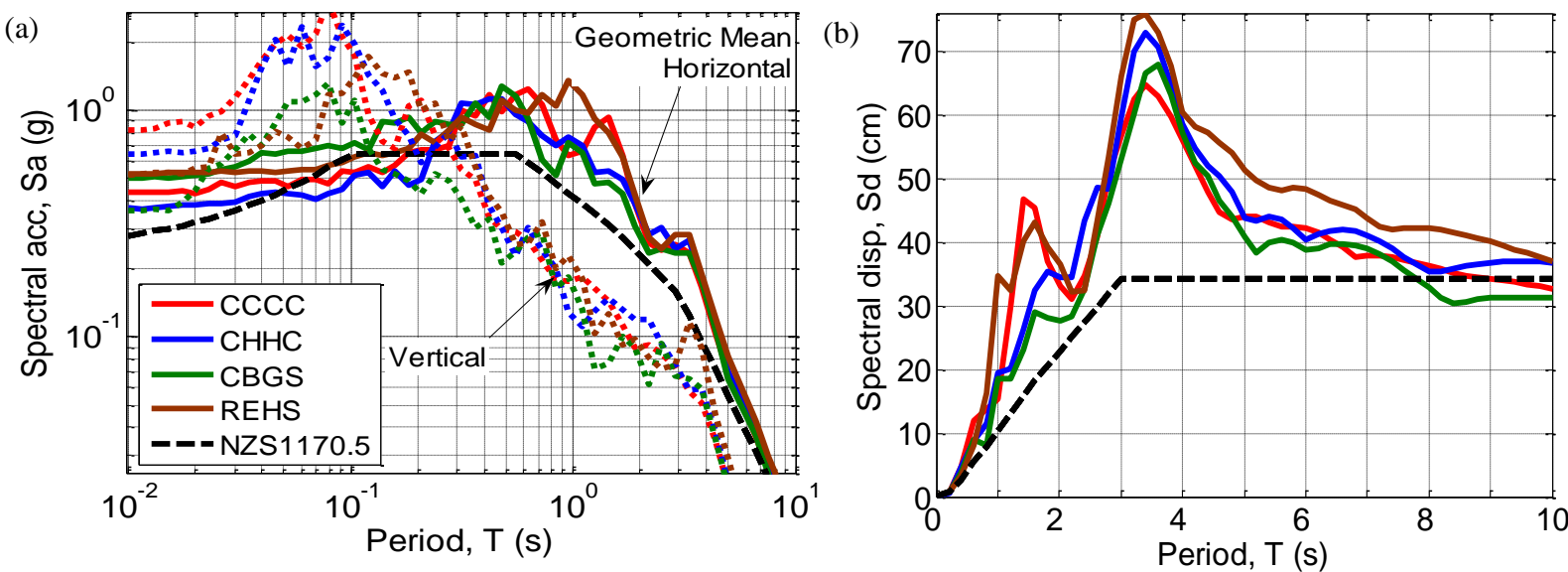

Figure 3: Comparison of response spectra from four strong motion stations located in the Christchurch central business district: (a) horizontal and vertical pseudo-acceleration response spectra; and (b) horizontal displacement response spectra [8].

\section{Seismic intensity in the CBD}

The Christchurch earthquake caused significant damage to commercial structures in the CBD. Figure 3 illustrates the pseudo-acceleration and displacement response spectra of four strong motion stations (CCCC, CHHC, CBGS, REHS) located in the CBD. Despite their geographic separation distances (relative to their respective source-to-site distances) it can be seen that the characteristics of the ground motion observed at these locations is relatively similar. This is particularly the case for long-period ground motion amplitudes, which have longer wavelengths, while there is more of a discrepancy in seismic intensity at short periods due to lower wave coherency and the importance of near-surface soil layers (which are highly variable as discussed subsequently). Figure 3 , in particular, illustrates that the seismic demands were above the 475 year return period design ground motion for Christchurch site class D as specified by the New Zealand loading standard, NZS1170.5 [9]. Figure 3b also illustrates that for structures whose secant period at peak displacement is in the region of 1.5 or 3.5 seconds, the displacement demands imposed by the ground motion were in the order of two times the seismic design level.

\section{OVERVIEW OF OBSERVED LIQUEFACTION}

\section{Spatial extent of liquefaction in the 22 February 2011 earthquake}

A distinctive feature of the 22 February 2011 earthquake, as well as other recent events which have produced strong ground shaking in Christchurch city, was the severity and spatial extent of liquefaction observed in native soils. Figure 4 shows the extent of liquefaction caused by the 22 February 2011 earthquake in the greater Christchurch region based on a drive-through reconnaissance [10]. Four areas of different liquefaction severity are indicated in the map: (a) moderate to severe liquefaction (red zone, with very large areas covered by sand ejecta, large cracks and fissures in the ground, and significant liquefaction-induced impacts on buildings), (b) low to moderate liquefaction (yellow zone, with generally similar features as for the severe liquefaction, but of lesser intensity and extent), (c) liquefaction predominantly on roads with some on properties (magenta zone), and (d) traces of liquefaction (red circular symbols, with clear signs of liquefaction, but limited in extent and deemed not too damaging for structures). Blue lines indicate areas where no surface manifestation of liquefaction was evident. As elaborated upon later, the suburbs to the east of the CBD along the Avon River (Avonside, Dallington, Avondale, Burwood and Bexley) were most severely affected by liquefaction.

\section{Repeated liquefaction}

Soil liquefaction repeatedly occurred at some sites during the earthquakes producing strong ground shaking in Christchurch, and in particular during the 4 September 2010, 22 February 2011, and the $M_{w} 5.5$ and $M_{w} 6.013$ June 2011 earthquakes. Figure 5 comparatively shows liquefied areas of Christchurch in these three events, as documented by field investigations. The repeated liquefaction was often quite severe and many residents reported that in some cases the severity increased in subsequent events.

\section{LIQUEFACTION AND ITS EFFECTS IN THE CBD}

Salient observations of the effects of soil liquefaction on structures in the CBD of Christchurch are presented here including several important cases of buildings with varying foundation types that performed differently in liquefied ground, while further details can be found in Cubrinovski et al. [7].

\section{CBD soil characteristics}

The shallow alluvial soils vary substantially within short distances, both horizontally and vertically within the CBD (as well as the greater Christchurch region in general). This variation is depicted in Figure 6, where a simplified stratification up to $30 \mathrm{~m}$ depth is shown for a cross section through the CBD soils along Hereford Street [11]. To further illustrate the spatial variability of foundation soils, Figure 7 delineates several zones indicating the predominant soils in the top 7 to $8 \mathrm{~m}$ of the CBD deposits [12]. In the south-west part of the CBD, alluvial gravels are encountered at shallow depths of $2.5 \mathrm{~m}$ to $3.5 \mathrm{~m}$, while loose silts and peat comprise the top soils in the south-east part of the CBD. Relatively clean and deep sands dominate the stretch along Avon River; this was the area most severely affected by liquefaction in the 22 February earthquake. Further to the north of this zone towards Bealey Avenue, loose silty soils and peat are encountered in the top 7 to $8 \mathrm{~m}$ of the deposit. 


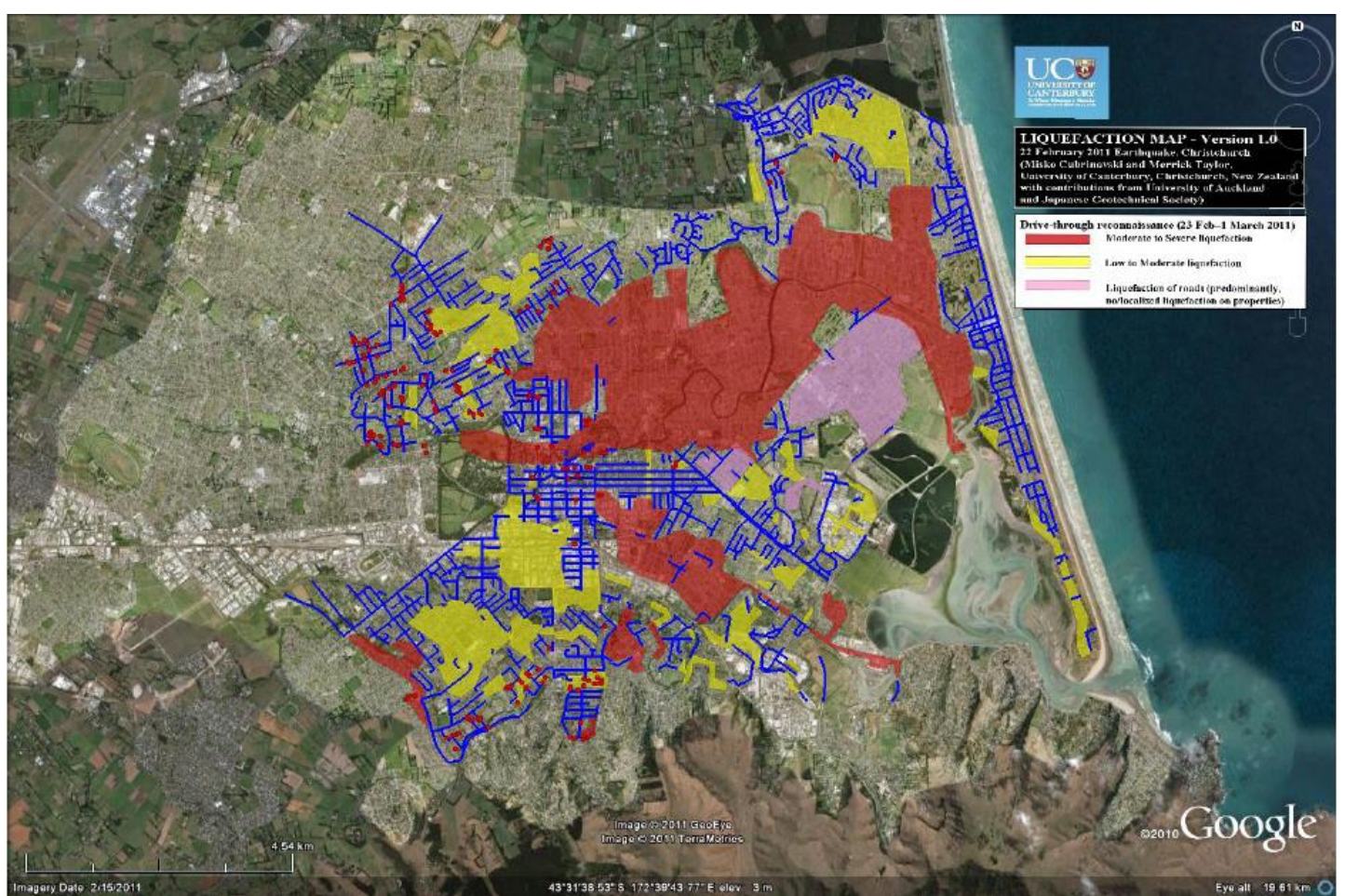

Figure 4: Preliminary liquefaction map of Christchurch from drive-through reconnaissance [10]

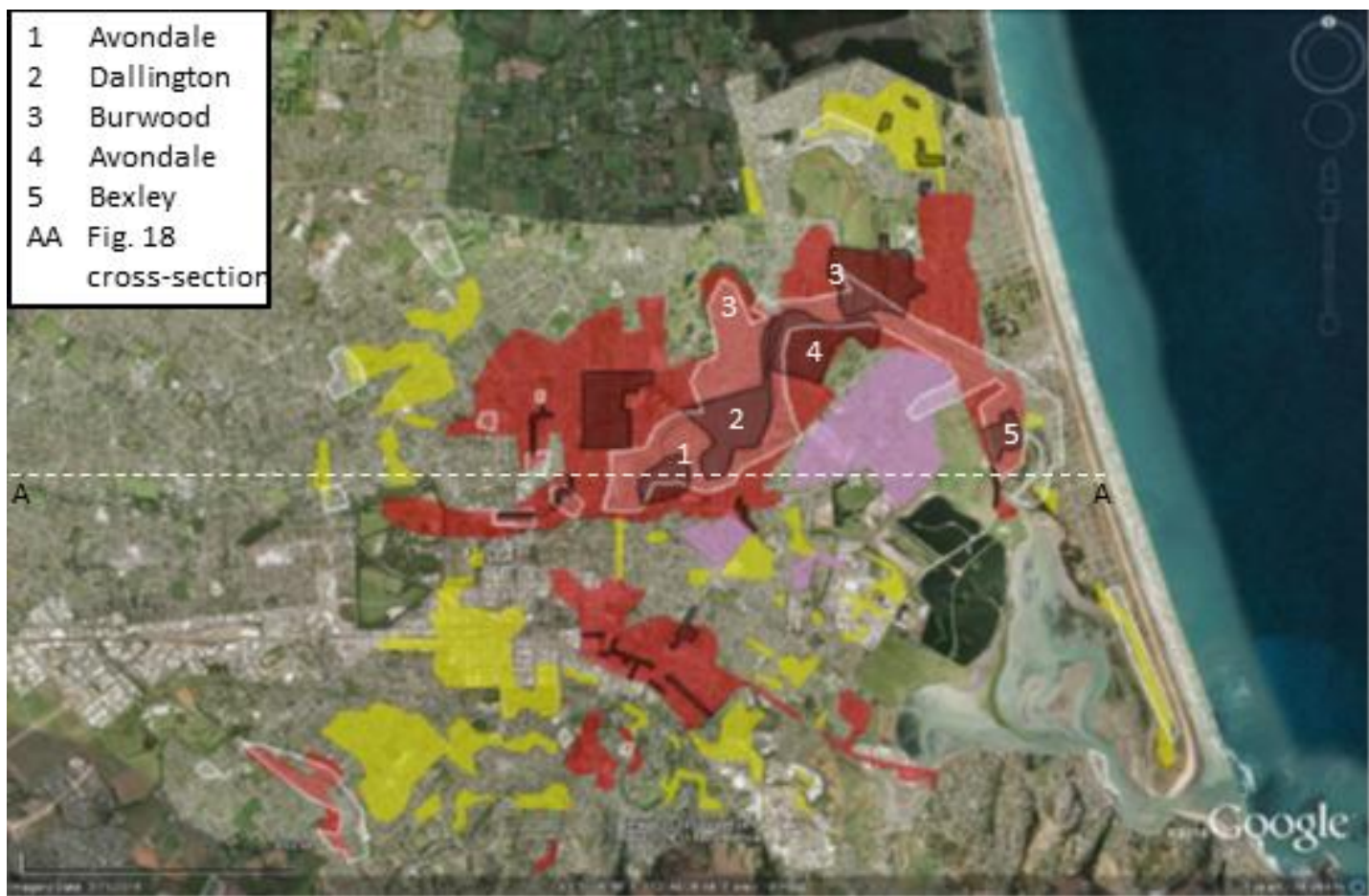

Figure 5: Preliminary liquefaction maps documenting areas of observed liquefaction in the 4 September 2010 (white contours), 22 February 2011 (red, yellow, magenta areas), and 13 June 2011 (black contours) earthquakes [12].

\section{Spatial distribution of liquefaction in the CBD}

Figure 7 shows the resulting liquefaction documentation map for the CBD. The principal zone of liquefaction stretches west to east through the CBD, from Hagley Park in the west, along the Avon River to the northeast boundary of the CBD at the Fitzgerald Avenue Bridge. This zone is of particular interest because many high-rise buildings on shallow foundations and deep foundations were affected by the liquefaction in different ways. Note that this zone consists mostly of sandy soils and largely coincides with the path of the Avon River and network of old streams shown in 1850's survey maps [12]. The performance of the surficial soils in the 22 February 2011 earthquake is also significant because liquefaction-induced damage in the CBD was limited in the $4^{\text {th }}$ September 2010 earthquake.

Even though the map shown in Figure 7 distinguishes the zone most significantly affected by liquefaction, the severity of liquefaction within this zone was not uniform. The manifestation of liquefaction was primarily of moderate intensity with relatively extensive areas and volumes of sediment ejecta (Figure 8). There were also areas of low manifestation or only traces of liquefaction, as well as pockets of severe liquefaction with very pronounced ground distortion, fissures, large settlements and substantial lateral ground movements. This non-uniformity in liquefaction manifestation reflects the complex and highly variable soil conditions even within the $\mathrm{CBD}$ principal liquefaction zone. 


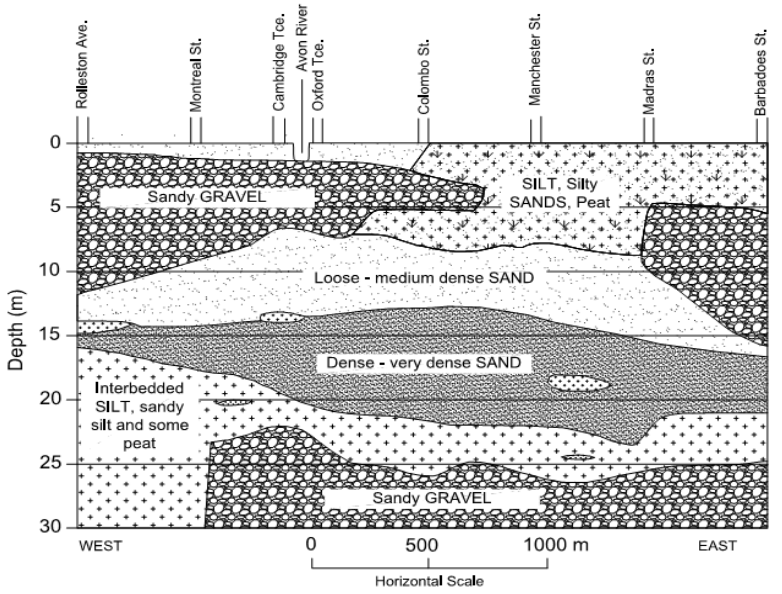

Figure 6: Representative subsurface cross section of Christchurch CBD along Hereford Street [11].

The northern extent of the zone, which is shown by the thick solid line in Figure 7, is a clearly defined geomorphic feature running east-west that was delineated by a slight change in ground elevation of about $1 \mathrm{~m}$ to $1.5 \mathrm{~m}$ over approximately 2 $\mathrm{m}$ to $10 \mathrm{~m}$ wide zone. After the 22 February event, it was further characterized by ground fissuring or distortion associated with localized spreading, as well as gentle slumping of the ground surface on the down slope side. Ground cracks, fissures and a distorted pavement surface marked this feature, which runs continuously through properties and affected a number of buildings causing cracks in both the foundations and superstructures. Liquefaction and associated ground deformation were pronounced and extensive on the down slope side between the identified geomorphic feature and the Avon River, but noticeably absent on the slightly higher elevation to the north (upslope side away from the river). This feature is thought to delineate the extent of a geologically recent river meander loop characterized by deposition of loose sand deposits under low velocity conditions. A similar geomorphic feature was observed delineating the boundary between liquefaction damage and unaffected ground within a current meander loop of the river to the east of this area (Oxford Terrace between Barbadoes Street and Fitzgerald Avenue).

\section{Ground Failure Effects on Nearly Identical Structures - East Salisbury Area}

A mini-complex of three nearly identical buildings (with one small but important difference) is shown in Figure 9. The buildings are three-storey structures with a garage at the ground floor, constructed on shallow foundations. This case clearly illustrates the impact of liquefaction, with nearly identical structures built across the east-west trending geomorphic feature identified previously in Figure 7, one

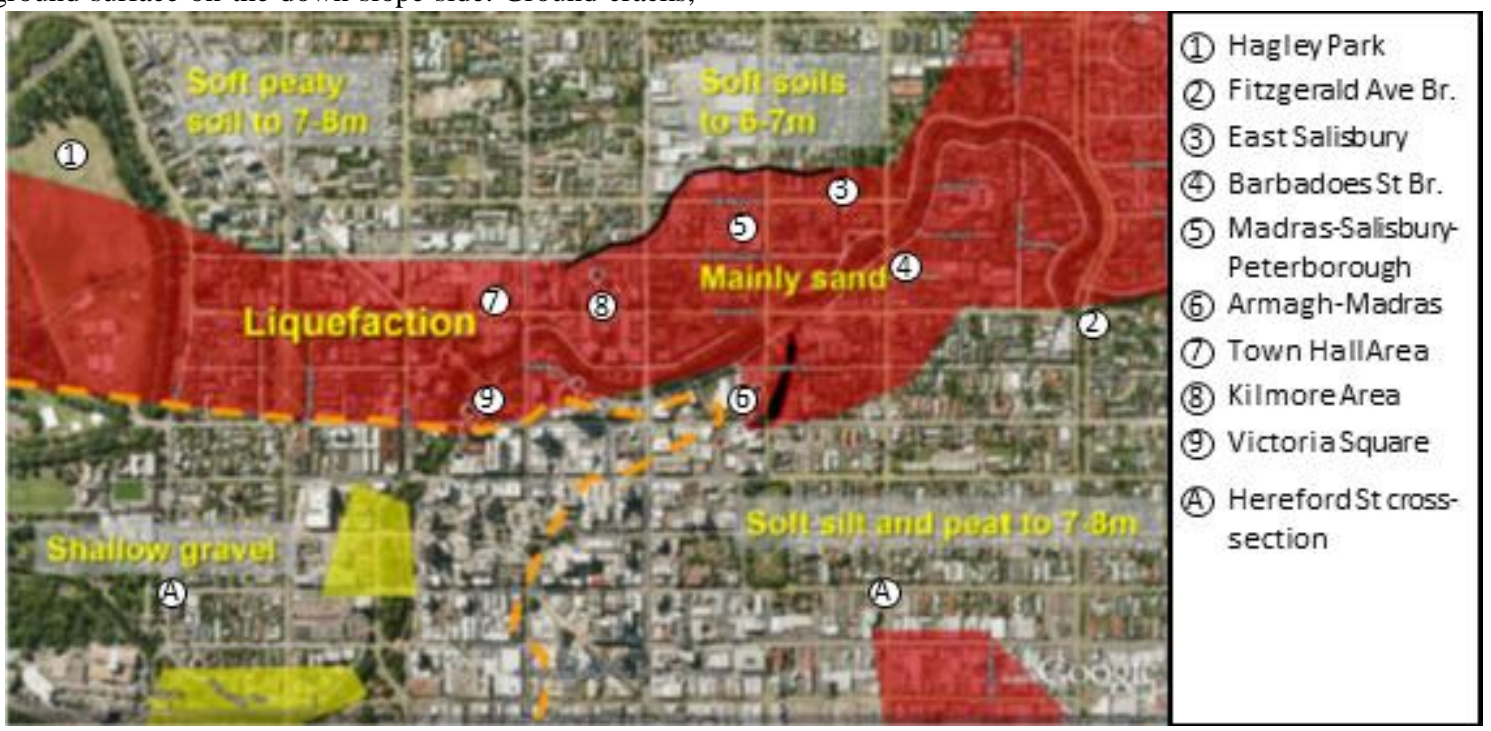

Figure 7: Preliminary CBD liquefaction map for the 22 February earthquake [10]; predominant soils in the top part of the deposits are also indicated [12].
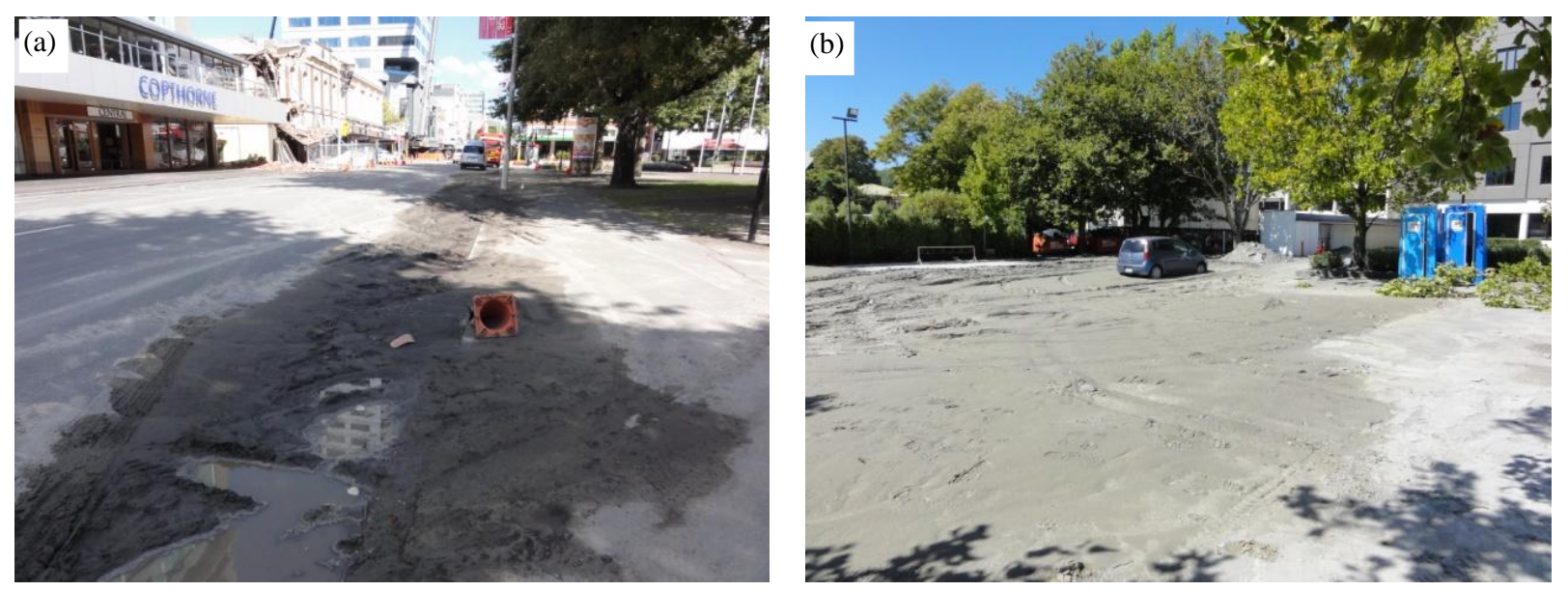

Figure 8. Representative areas of: (a) moderate liquefaction; and (b) severe liquefaction within the CBD principal liquefaction zone [7]. 

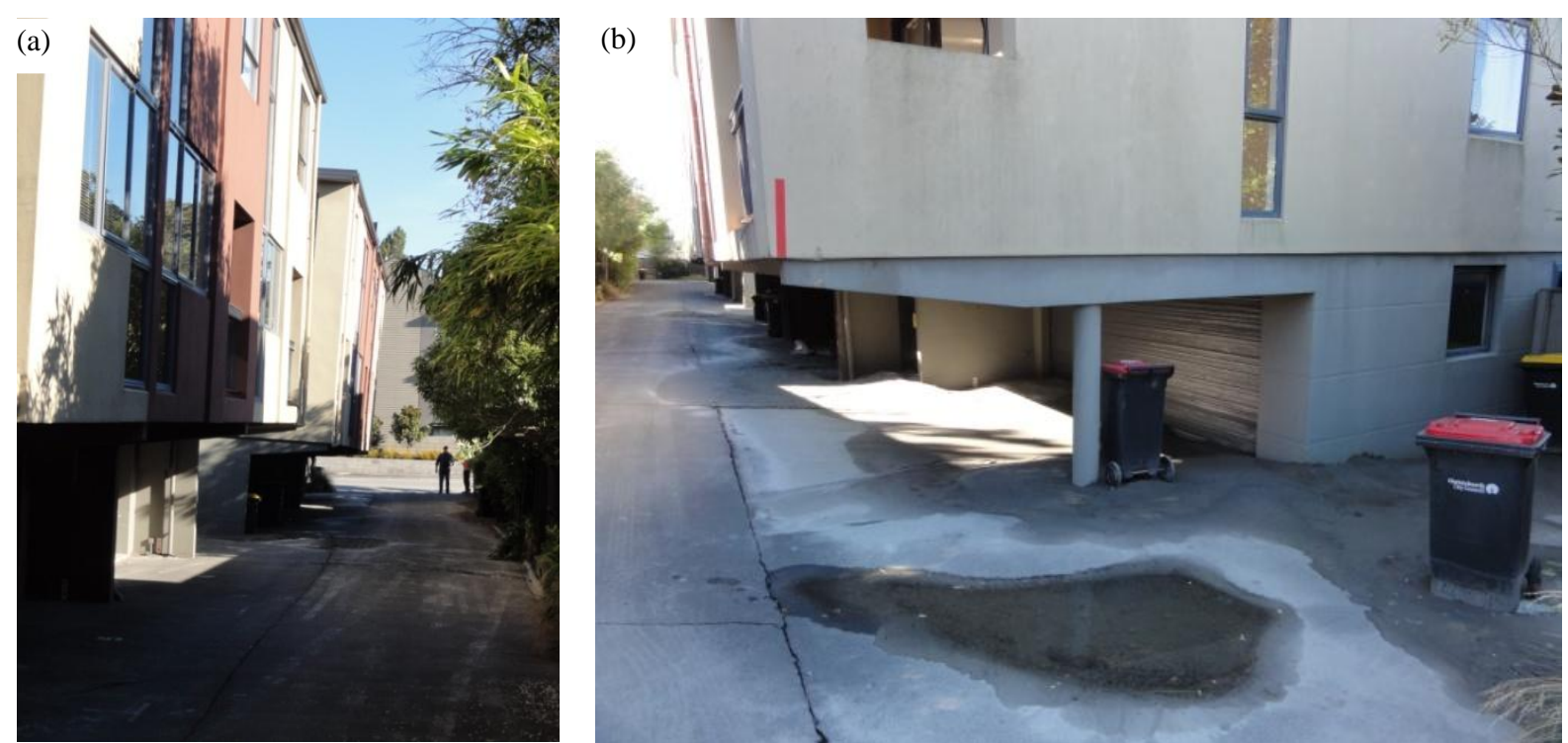

Figure 9: Apartment complex: (a) looking south from northern building showing tilt of southern building, and (b) looking north at liquefaction feature at edge of southern building [7].

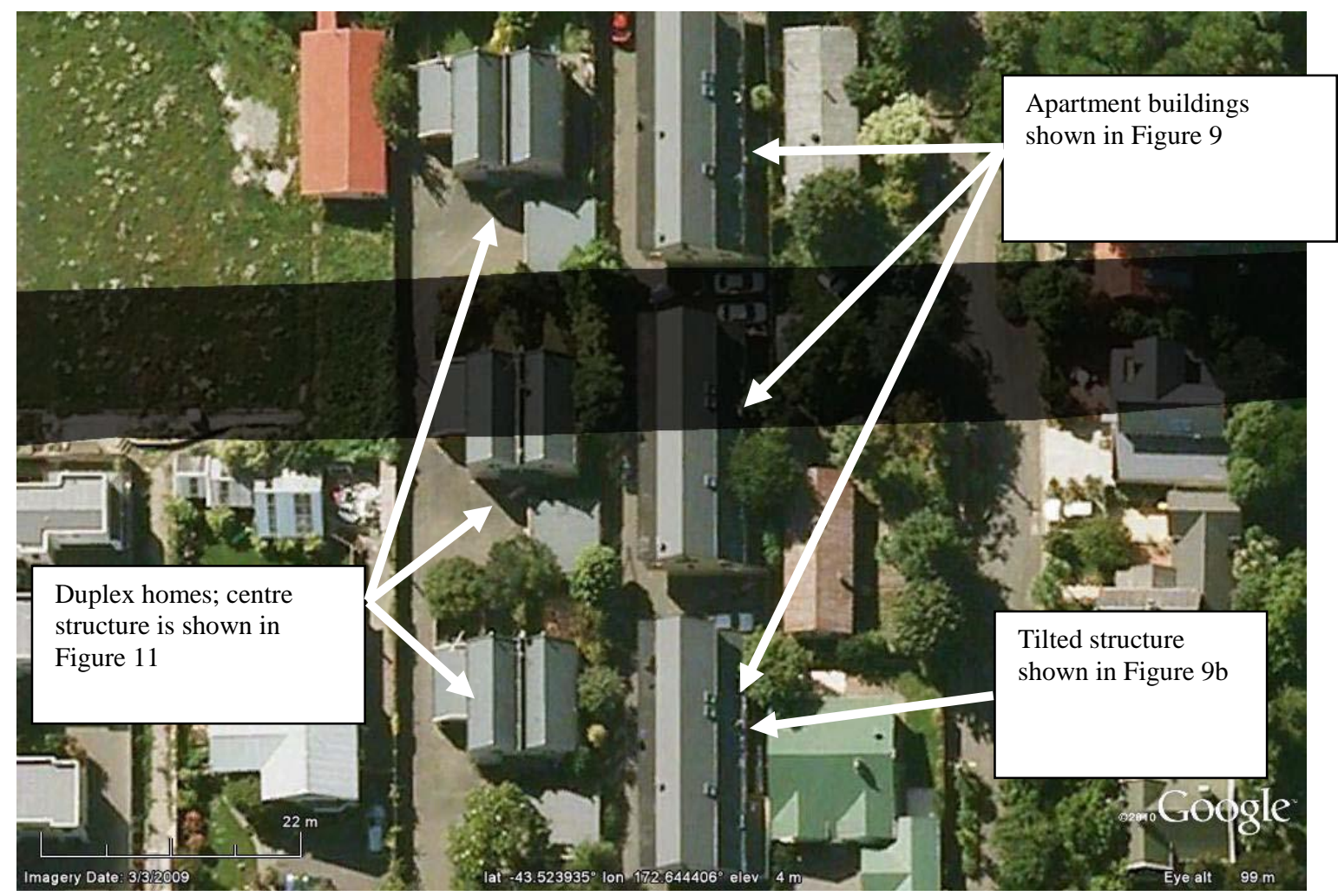

Figure 10: Location of geomorphic feature in area of apartment and duplex complexes north of Salisbury Street in CBD [7].
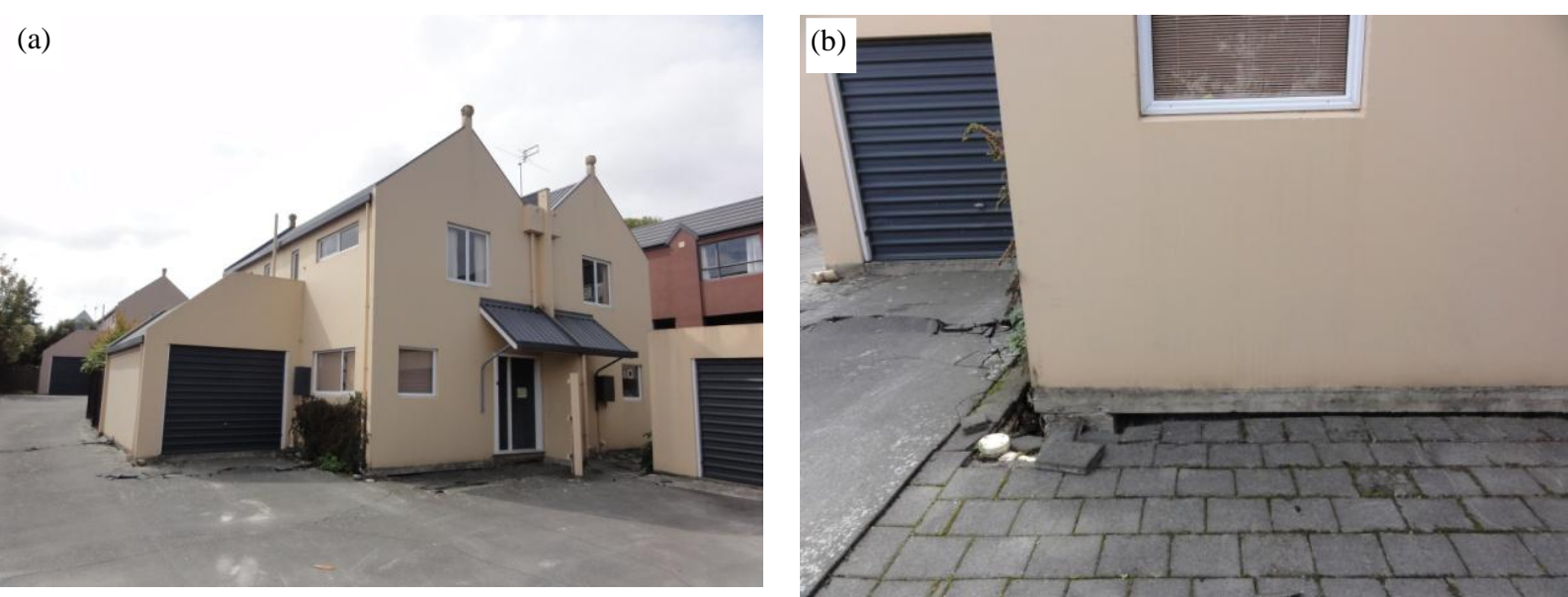

Figure 11: Duplex housing complex: (a) looking north at centre building, and (b) close-up of ground settlement next to centre building [7]. 
building located on the higher level to the north suffering no damage, and the buildings located below the crest suffering progressively higher amounts of damage. This geomorphic feature, which is expressed here by a significant change in grade of the pavement between the northern and middle buildings, is shown in Figure 10. The northern building that sits on the higher ground showed no evidence of cracking and distortion of the pavement surface. Conversely, large sediment ejecta were found along the perimeter of the southern building indicating severe liquefaction in its foundation soils (Figure $9 b$ ). Liquefaction features were also observed near the middle building, but the resulting distress of this building was significantly less than that of the southern building. The southern building had a shortened end wall with a column at its southwest corner, which appeared to produce additional settlement at the location of the column's concentrated load. It suffered differential settlement of about $40 \mathrm{~cm}$ and over 3 degrees of tilt towards the west-southwest, which is visible in Figure 9a. This building was uneconomical to repair and was demolished after the 22 February 2011 earthquake. Adjacent to these buildings is another complex of three identical but structurally different buildings from the former set. Their locations relative to the abovementioned geomorphic feature is identical, but these buildings are two-storey duplexes. Figure 11a shows the middle building with clear evidence of pavement distortion, cracking and settlement of the surrounding ground. The settlement of the building was likely not significant, but the ground settled about $20 \mathrm{~cm}$ exposing the top of the foundation at the southwest corner (Figure 11b).

Another apartment complex that was constructed on a single level basement that extends almost the full length of the complex and provides off-street parking for the development lies to the west of the two case histories discussed previously. It also crosses the geomorphic feature. Noticeable settlement of the ground at the southern end of the complex of the order of 15-20 cm occurred and compression features in the pavement suggest that it displaced laterally towards the street. The concrete basement floor and structure appeared to have undergone negligible distortion, which indicates an overall rigid response despite the differential ground movements across the site.

\section{Punching Settlement - Madras-Salisbury-Peterborough Area}

Several buildings with shallow foundations located within the liquefied zone underwent punching settlements with some undergoing significant differential settlements. An example of such performance is shown in Figure 12 for a two-storey industrial building located $200 \mathrm{~m}$ south-west of the buildings discussed previously. There was clear evidence of the mudwater ejecta on the walls of the building indicating about 25 $\mathrm{cm}$ thick layer of water and ejected soils due to the severe liquefaction. Note the continuous sand ejecta around the perimeter of the footing and signs of punching shear failure mechanism in Figure 12. At the front entrance of the building large ground distortion and sinkholes were created due to excessive pore water pressure and upward flow of water. Settlement of the building around its perimeter was evident and appeared substantially larger than that of the surrounding soil that was unaffected by the building. The building settled approximately $25 \mathrm{~cm}$ relative to a fence at its south-east corner and settled $10-20 \mathrm{~cm}$ relative to the ground at its north-west corner. The ground floor at the entrance was uplifted and blistered which is consistent with the pronounced settlement beneath the walls or along the perimeter of the building.

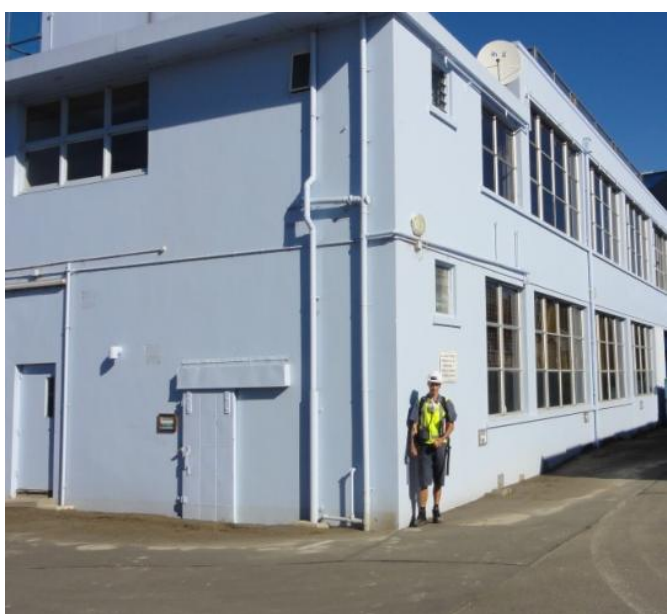

Figure 12: Two-story building that underwent liquefactioninduced punching movements [7].

\section{Differential Settlement and Sliding - Armagh-Madras Area}

Further to the south at the intersection of Madras and Armagh Streets, several buildings were affected by severe liquefaction that induced significant differential settlements or lateral movements. At this location, the liquefaction was manifested by a well-defined, narrow zone of surface cracks, fissures, and depression of the ground surface about $50 \mathrm{~m}$ wide, as well as water and sand ejecta (Figure 13a, and the wide black zone to the south of the Avon River in Figure 7).

This zone stretches from the Avon River to the north towards the buildings, which were affected by this liquefaction feature. Traces of liquefaction were evident further to the south of these buildings. Figure $13 \mathrm{~b}$ and Figure $13 \mathrm{c}$ illustrate two buildings, founded on isolated shallow foundations, that were located on the edges of the well-defined liquefaction zone in Figure 13a. It can be seen that for both structures lateral displacements, differential settlements, and consequent tilting were observed. Both buildings were considered uneconomical to repair and will be demolished.

\section{Performance of Adjacent Structures - Town Hall Area}

The Christchurch Town Hall for Performing Arts is located within the northwest quadrant of the $\mathrm{CBD}$, with the meandering Avon River to its immediate south. It is a complex facility comprising a main auditorium (seating 2,500) with adjoining entrance lobby, ticketing, and café areas. Further extensions provide a second, smaller auditorium James Hay Theatre (seating 1,000) and a variety of function rooms and a restaurant. The structures are supported on shallow foundations, except the kitchen facility that was added later. Air bridges connect the complex to the Crowne Plaza, a major hotel, and to the Christchurch Convention Centre (opened 1997) to the north. Tiled paved steps lead from the southern side of the complex down to the river's edge.

The facility suffered extensive damage primarily caused by liquefaction-induced ground failure. Differential settlements caused by punching shear beneath the building's main internal columns that surround the auditorium and carry the largest dead loads to shallow foundations and a second ring of exterior columns (Fig. 14a) that are connected to the inner ring via beams (Fig. 14b) caused distortion to the structure. The cracked beam shown in Fig. 14b underwent an angular distortion of $1 / 70$ across its span. The seating for the auditorium has been tilted; dragged backward by the settlement of the columns, leaving a large bulge or doming to the floor of the auditorium itself. The air bridge connecting the main auditorium to the Christchurch Convention Centre to the north (away from river) has separated from the building. 




Figure 13: Relatively narrow liquefaction-induced feature and induced differential settlement and sliding of buildings [7].

With no significant deformations of the ground as the obvious source of this lengthening between the two buildings, the explanation appears to be that distortions to the auditorium structure have pulled the outer walls in towards the building, creating this separation. The entire complex appears to have moved laterally towards the river (albeit by a barely perceptible amount on the northern side) with parts of the complex closest to the river undergoing increasingly larger movements (Fig. 14c). These sections have settled and moved laterally towards the river more than the remainder of the building leading to significant structural deformations where the extension and original structures are joined.

Contrary to the liquefaction-induced punching settlement of buildings into the surrounding ground that was observed at the Town Hall and in other parts of the CBD, the seven-storey building on shallow foundations shown in Figure 15a did not punch significantly into the liquefied ground nor undergo significant differential settlement. As shown in Figure 15b there were significant amounts of sand ejecta observed in this area. However, there was no obvious evidence of significant differential ground or building movement. The differential settlement measured between adjacent columns was typically negligible, but differential settlements of up to $3.5 \mathrm{~cm}$ were measured at a few locations. This building is across the street and slightly to the west of the Town Hall. It is a case of liquefaction without significant differential settlement and building damage.
Contrasting Performance of a Pile-Supported Structure Kilmore Area

Several pile-supported structures were identified in areas of severe liquefaction. Although significant ground failure occurred and the ground surrounding the structures settled, the buildings supported on piles typically suffered less damage. However, there are cases where pile-supported structures were damaged in areas that underwent lateral spreading near the Avon River. In other cases, such as the building shown in Figure 16, located approximately $200 \mathrm{~m}$ to the east from the Town Hall, the ground floor garage pavement was heavily damaged in combination with surrounding ground deformation and disruption of buried utilities. The settlement of the surrounding soils was substantial with about $30 \mathrm{~cm}$ of ground settlement on the north side of the building and up to $17 \mathrm{~cm}$ on its south side. The first storey structural frame of the building that was supported by the pile foundation with strong tie-beams did not show significant damage from these liquefaction-induced ground settlements. Following the 13 June 2011 earthquakes, the settlement of the surrounding soil at the north side of the building reached about $50 \mathrm{~cm}$.

Across from this building to the north, is a seven-storey reinforced concrete building on shallow spread footing foundations that suffered damage to the columns at the ground level. This building tilted towards south-east as a result of approximately $10 \mathrm{~cm}$ differential settlement caused by the more severe and extensive liquefaction at the south, south-east part of the site. Hence, these two buildings provide invaluable information on the performance of shallow foundations and pile foundations in an area of moderate to severe liquefaction 
that induced uneven ground settlements. At this site, extensive field investigations were conducted including shear wave velocity profiling and a dense array of CPTs and Gel-Push sampling of undisturbed samples of sandy and silty soils from $2 \mathrm{~m}$ to $13 \mathrm{~m}$ depth.
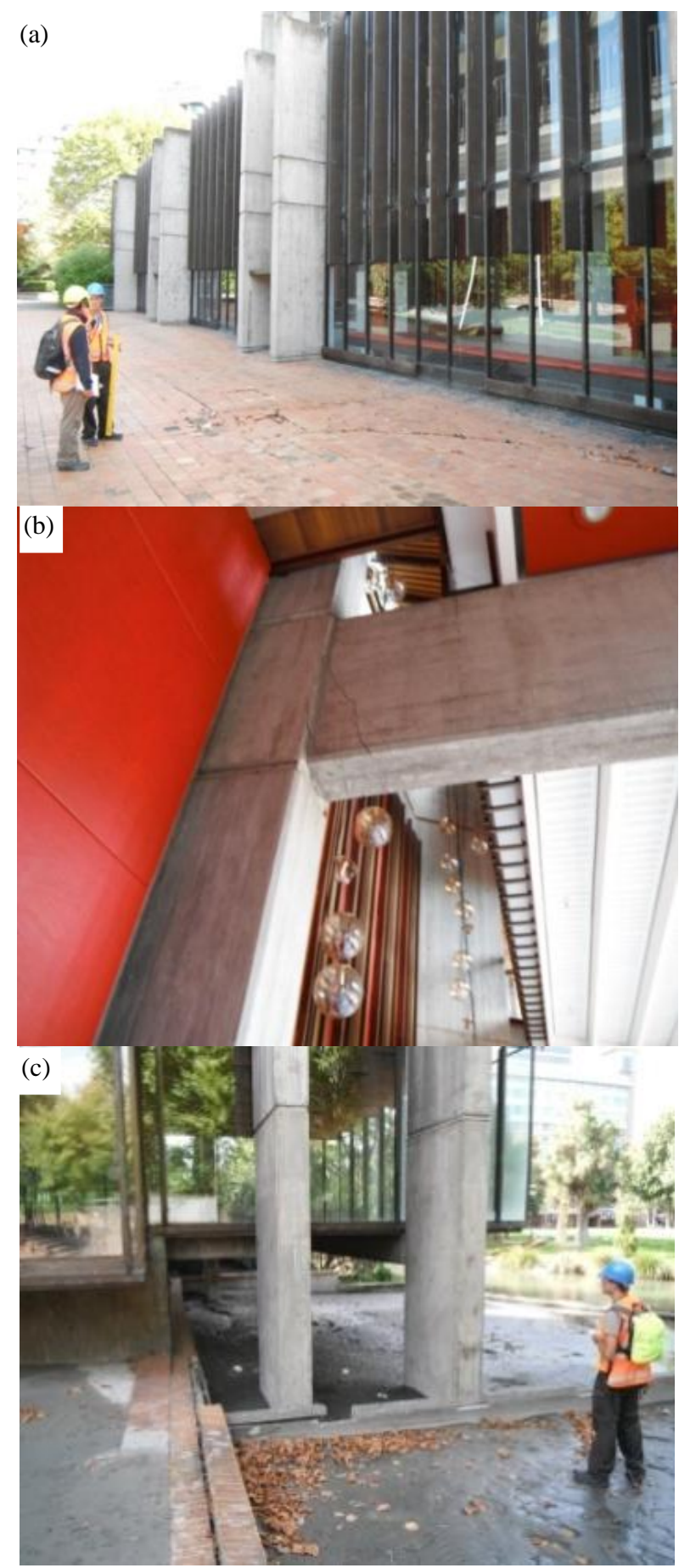

Figure 14: Town Hall auditorium and adjacent dining facility undergoing significant liquefactioninduced differential settlement and lateral movements [7].
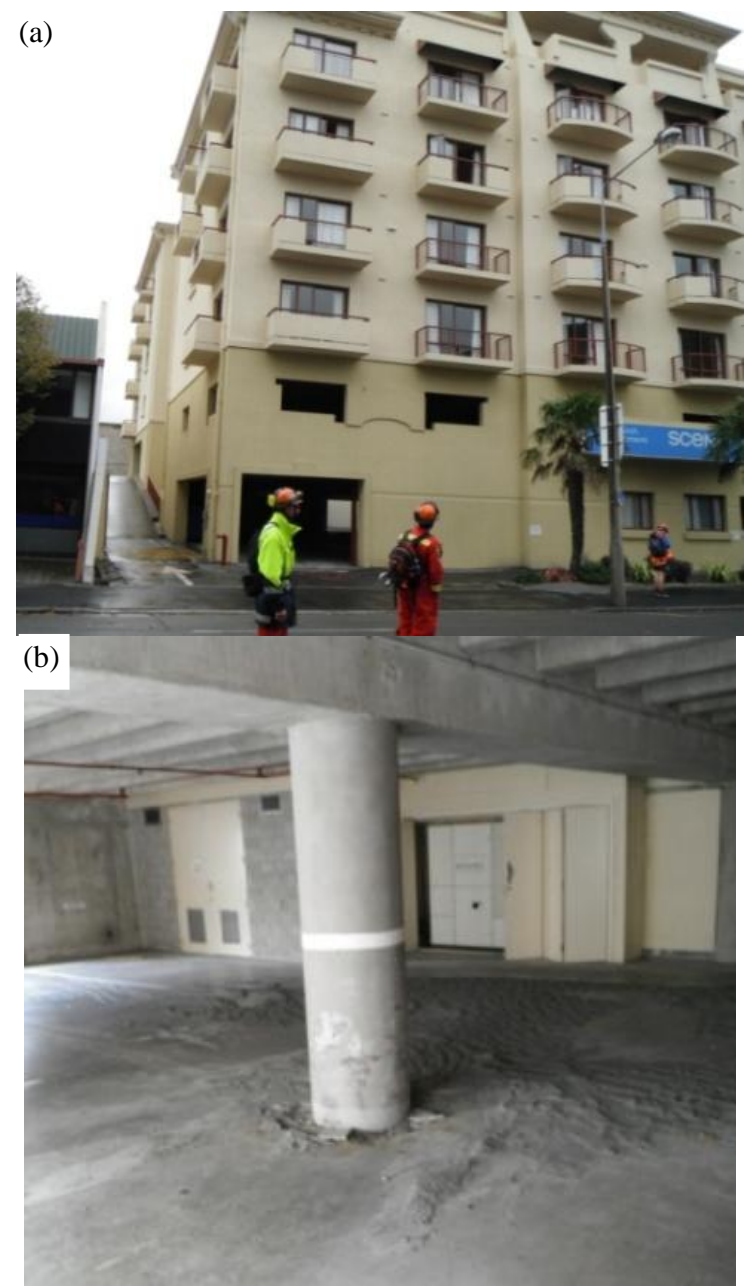

Figure 15: Building in area of significant liquefaction that displays negligible to minor differential settlement or punching settlement [7].

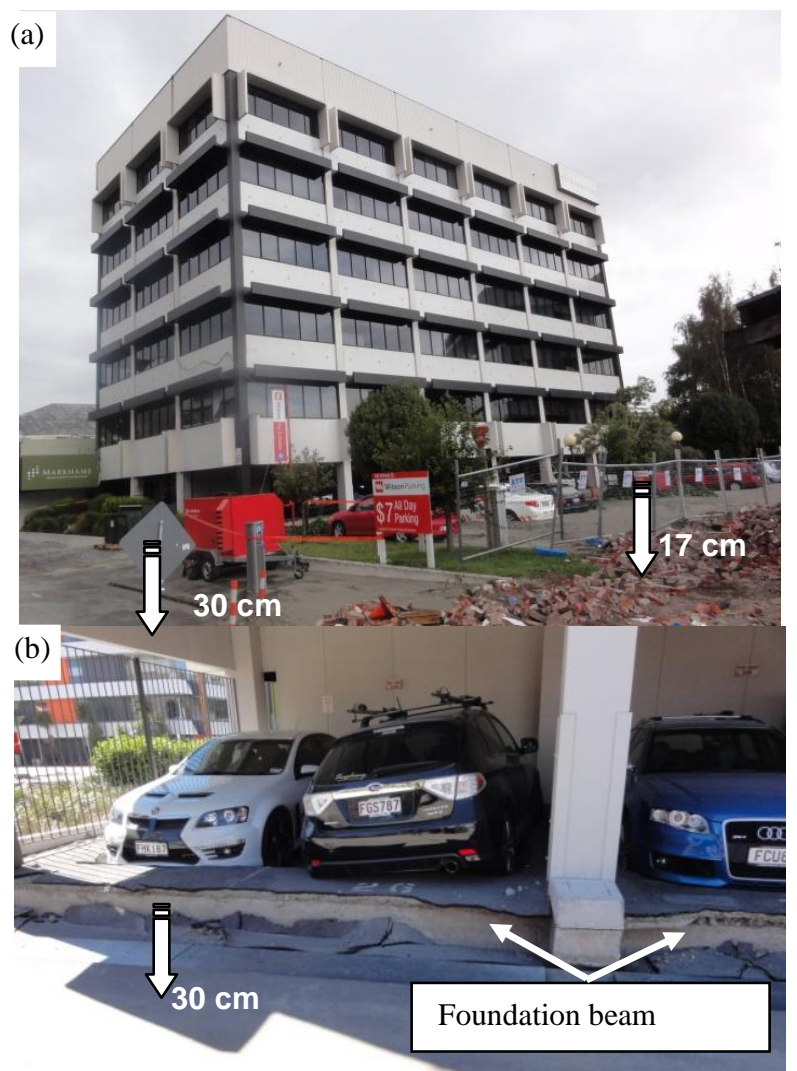

Figure 16: Building on pile foundations in area of severe liquefaction showing large settlement of the surrounding soils relative to the foundation beams [7]. 


\section{Presence of Shallow Gravelly Soils - Victoria Square}

Near Victoria Square, the liquefied zone was predominantly composed of relatively loose sand deposits that transitioned relatively sharply into a zone where gravelly soil layers reach close to the ground surface. Shallow foundations (spread footings and rafts) for many of the high-rise buildings in this latter area are supported on these competent gravelly soils. However, the ground conditions are quite complex in the transition zone, which resulted in permanent lateral movements, settlements, and tilt of buildings either on shallow foundations or hybrid foundation systems (with both shallow and pile foundation elements), as illustrated in Figure 17. Immediately to the north of these buildings, the liquefaction was severe with massive sand ejecta; however, approximately $100 \mathrm{~m}$ further to the south where the gravels predominate, there was neither evidence of liquefaction on the ground surface nor visible distress of the pavement surface. Again, it appears that the ground and foundation conditions have played a key role in the performance of these buildings, with these buildings, accordingly, being selected for further in-depth inspections and field investigations.

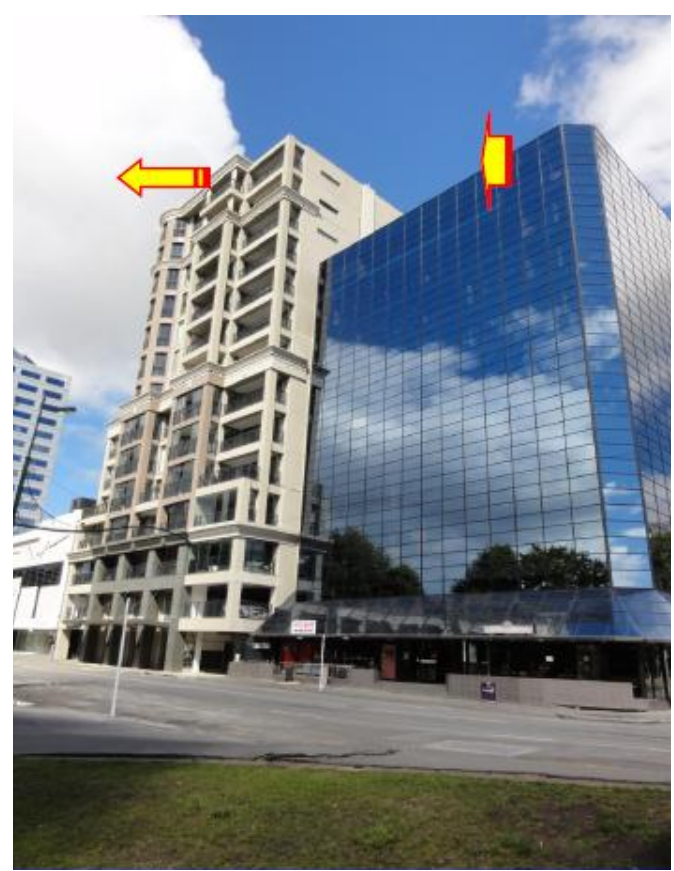

Figure 17: Buildings on shallow and hybrid foundations in transition area from moderate liquefaction to low/no liquefaction; arrows indicate direction of tilt of the buildings [7].

\section{Lateral Spreading - Avon River within CBD}

Liquefaction-induced lateral spreading was evident within the CBD along the Avon River in the liquefied zone, and the horizontal stretching of the ground adversely affected several buildings. Detailed measurements by ground surveying conducted at about 10 transects on Avon River within the CBD after the 22 February earthquake indicated that at several locations the maximum spreading displacements at the banks of Avon River reached about 50-70 cm, whereas at most of the other locations the spreading was on the order of $10 \mathrm{~cm}$ to 20 $\mathrm{cm}$. There were many smaller buildings suffering serious damage to the foundations due to spreading as well as clear signs of effects of spreading on some larger buildings both at the foundations and through the superstructure.

\section{LIQUEFACTION AND ITS EFFECTS IN RESIDENTAL AREAS}

\section{Soil characteristics of residential areas}

As previously noted, the near-surface geology of Christchurch is dominated by fluvial processes and, as such, has highly variable soil properties. Despite this variability, gross features of the near-surface soil characteristics can be used to explain the observed ground response, particularly in suburban areas, as is the focus of this section.

Figure 18 provides a schematic illustration of an east-west cross-section of the near surface geology of Christchurch taken along Bealey Avenue (location shown in Fig. 5). Important features of this figure include a water table with depth of approximately only $1 \mathrm{~m}$ below the surface in almost the entire eastern side of the city (with the exception of those colluvium areas at the base of the Port Hills to the south); and an increasing depth of Riccarton gravel horizon, the upmost aquifer beneath the city. Although not shown in Figure 18 it is also noteworthy that the Springston formation (alluvial gravels, sands and silts) is the dominant surface layer in the west of Christchurch, and the Christchurch formation (estuarine, lagoon, beach, dune, and coastal swamp deposits of sand, silt, clay and peat) to the east of Christchurch. Hence, it can be argued that the significant liquefaction observed in the eastern suburbs of the city, and the absence in the west of the city can be attributed to several contributing factors: (i) a reduction in the amplitude of ground shaking moving from east to west (i.e. Figure 1 and Table 1); (ii) a gradual change in surficial soil characteristics; and (iii) an increase in water table depth.

In both (4 September 2010 and 22 February 2011) earthquakes, widespread liquefaction occurred in the urban areas of Christchurch and Kaiapoi causing extensive damage to residential properties. The liquefaction was manifested by massive sand boils and large amount of sand/silt ejecta and water littering streets, residential properties and recreation grounds of Christchurch and Kaiapoi (town north of Christchurch shown in Fig. 21). Nearly 15,000 residential houses and properties were severely damaged due to liquefaction and lateral spreading, more than half of those beyond economical repair.

The distribution of liquefied areas shown in Figure 5 reflects the combined effects of two important factors for liquefaction triggering: the soil resistance to liquefaction (a measure for the capacity of soils to sustain cyclic loading) and the severity of ground motions (measure for the seismic load or demand) produced by the two quakes. The suburbs most severely affected by liquefaction in Christchurch were along the Avon River to the east and northeast of CBD (Avonside, Dallington, Avondale, Burwood and Bexley). The soils in these suburbs are predominantly loose fluvial deposits of liquefiable clean fine sands and sands with non-plastic silts. The top 5-6 m are in a very loose state, with a CPT cone resistance, $q_{c}$, of about 2-4 MPa. The resistance typically increases to 7-12 $\mathrm{MPa}$ at depths between 6 and $10 \mathrm{~m}$, however lower resistances are often encountered in areas close to wetlands. The more extensive liquefaction observed in these areas during the February 2011 earthquake is consistent with the fact that the seismic demand specific to liquefaction was about 1.5 to 2.0 times higher during the February event as compared to the September 2010 earthquake. Similarly, at the southwest end of the city in Hoon Hay and Halswell, more extensive liquefaction occurred during the 2010 Darfield earthquake. 


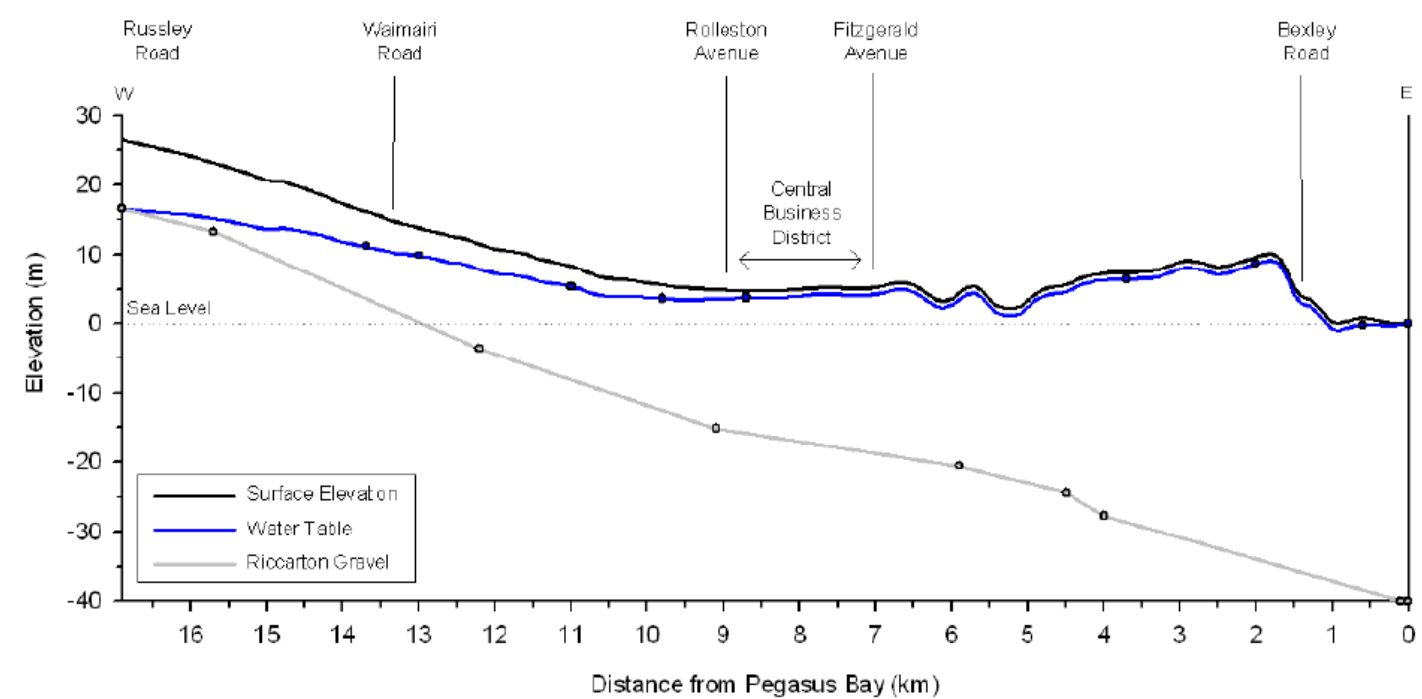

Figure 18: East-west cross-section of surface elevation, water table and Riccarton gravel horizon at Bealey Avenue in the NorthSouth direction [12].
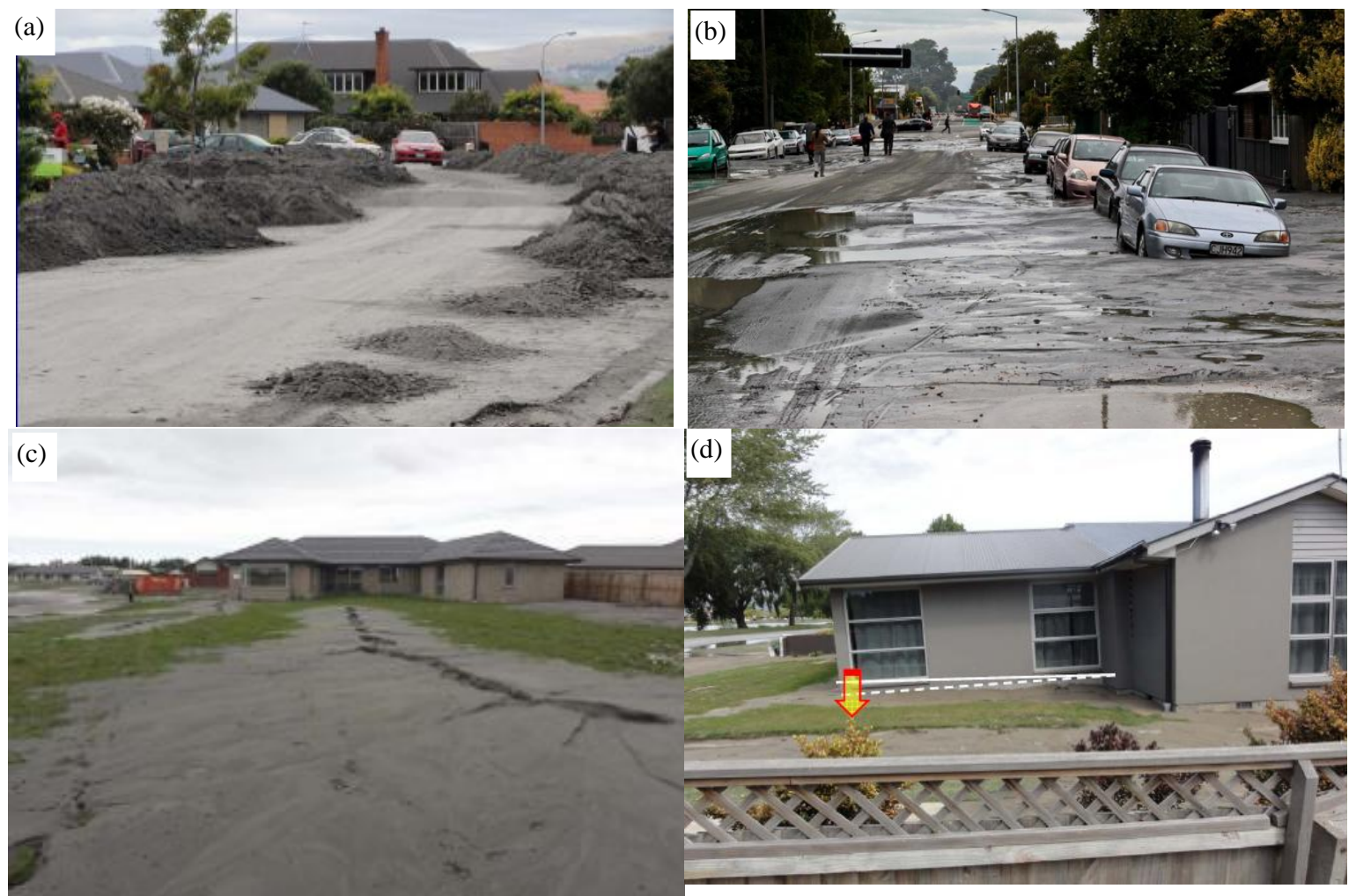

Figure 19: Typical manifestation of liquefaction in residential areas.
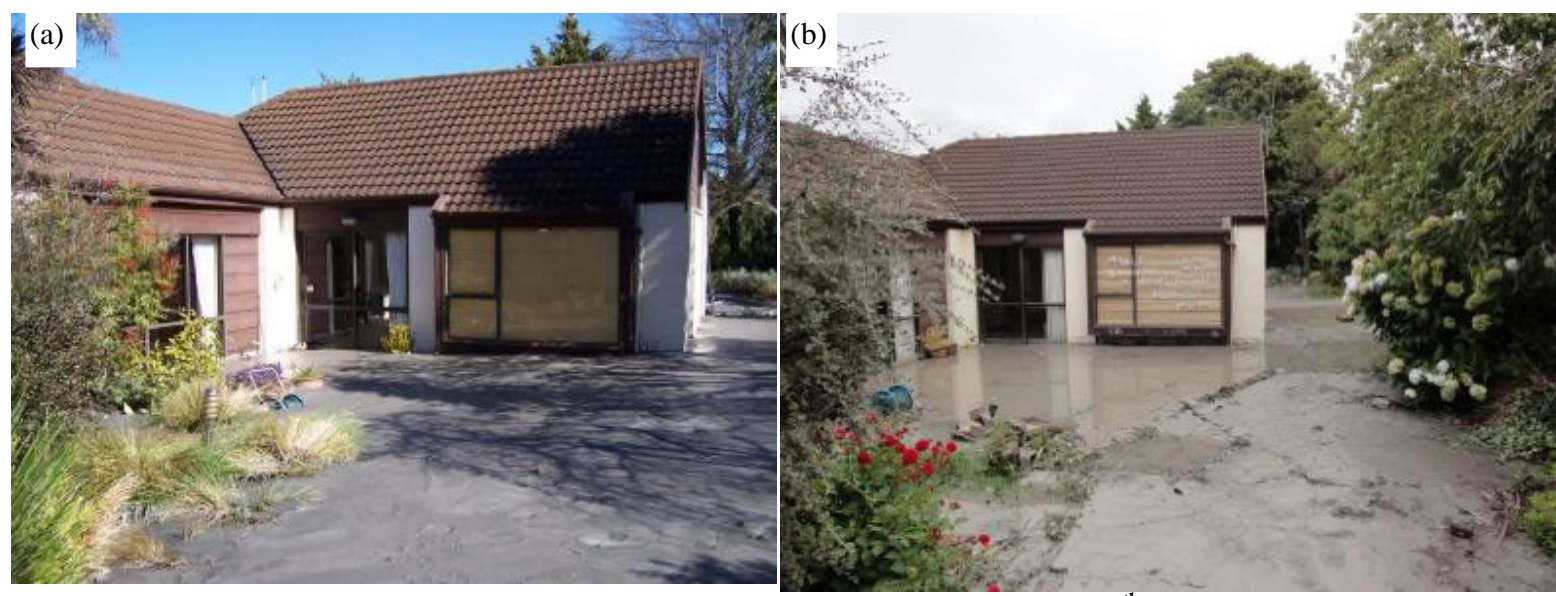

Figure 20: Illustration of a house in Kaiapoi which sustained liquefaction in both the (a) $4^{\text {th }}$ September 2010 Darfield; and (b) 22 February 2011 Christchurch earthquakes. 


\section{Typical damage in residential areas}

Total and differential settlements, lateral movements, and flooding due to liquefaction and lateral spreading is estimated to have severely affected 15,000 residential properties/buildings. Particularly, damage due to liquefaction related phenomena was widespread in the suburbs to the east of the CBD along the Avon River (Avonside, Dallington, Avondale, Burwood and Bexley). In these areas only moderate damage was directly due to inertial loading from ground shaking. About 5,000 residential properties in such suburbs will be abandoned due to the infeasibility of repair (New Zealand Government, 2011). Examples of damage as a result of liquefaction in the residential areas are presented in Figure 19 , with the volume of ejected material in residential properties indicated by the piles of sand in Figure 19a, a typical view in many streets following the Christchurch earthquake. Figure 19b provides a good indication of the flooding and ejected material in the streets themselves immediately following the earthquake. The large sand boils in Figure $19 \mathrm{c}$, about $20-30 \mathrm{~m}$ long and $10-15 \mathrm{~m}$ wide, indicate both a large severity and extent of liquefaction throughout the depth of the deposit. Figure 19d shows a typical differential settlement and damage to the building due to separation of walls as a result of loss of bearing capacity of the liquefied foundation materials.

Figure 20 indicates damage to a residence in Kaiapoi after the Darfield and Christchurch earthquakes. Following the Darfield earthquake there was large settlement of the ground and house, and approximately $40 \mathrm{~cm}$ of ejected material covering the ground surface. Site investigations performed following the Darfield earthquake indicated loose/soft soils up to depths of $9 \mathrm{~m}$. Ground motions were largest in Kaiapoi during the Darfield earthquake and lesser in the Christchurch earthquake (PGA's of approximately $0.33 \mathrm{~g}$ and $0.21 \mathrm{~g}$, respectively). Despite this, Figure 20b illustrates that the volume of ejected material following the Christchurch earthquake was again significant, and highlights the potential for repeated liquefaction during multiple earthquakes of the typical soil deposits in the region. A smaller volume of ejected material was again evident at this site following the 13 June 2011 earthquakes.

\section{Field investigations of soil characteristics}

Following the 22 February 2011 earthquake field investigations were performed in concert with documentation of observed damage. Here a summary of some of the methods and obtained data are given. Readers are referred to Green et al. [13] for further details. Other field investigations including comprehensive CPT, SPT and Gel-Push sampling of undisturbed soils are still in the phase of processing and interpretation.

The in-situ testing procedures discussed herein are: spectral analysis of surface waves (SASW), and dynamic cone penetrometer (DCP), which were used to estimate the shallow soil shear wave velocity and strength (via corrected SPT N values), respectively. The DCP used in the field tests utilizes a $6.8 \mathrm{~kg}$ mass on an E-rod slide drive to penetrate an oversized $45^{\circ}$ apex angle cone. The cone is oversized to reduce rod friction behind the tip. Experience has shown that the DCP can be used effectively in augered holes to depths up to $6.1 \mathrm{~m}$. The DCP tests consists of counting the number of drops of the 6.8 $\mathrm{kg}$ mass that is required to advance the cone $\sim 4.5 \mathrm{~cm}$, with the number of drops referred to as the DCP N-value or $\mathrm{N}_{\text {DCPT }}$, and can be correlated to SPT $\mathrm{N}$ value. The SASW field measurements in this study were made using three $4.5 \mathrm{~Hz}$ geophones, a 'pocket-portable' dynamic signal analyzer, and a sledge hammer. Each tests took less than 45 minutes per location and typically enabled $\mathrm{V}_{\mathrm{S}}$ profiles to be generated down to 6.1-9.1 $\mathrm{m}$ below the surface. The experimental surface waves dispersion curves obtained from the SASW testing were used to determine a best-fitting 1D shear wave velocity $\left(V_{s}\right)$ profile. In total, $30 \mathrm{DCP}$ and $36 \mathrm{SASW}$ tests were performed across Christchurch and its environs after the Darfield and Christchurch earthquakes as depicted in Figure 21.

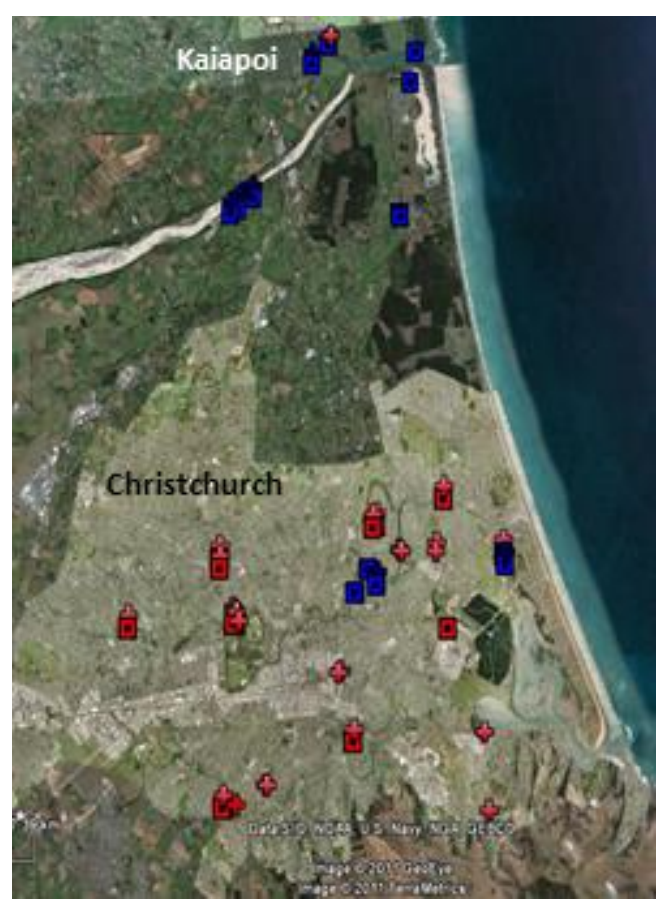

Figure 21: Locations of SASW (“+” symbol) and DCPT (“口” symbol) tests performed post-event. Blue sites are field tests post-Darfield earthquake, and red post-Christchurch earthquake.

For use in liquefaction assessment, the obtained (converted) SPT N-values and $V_{s}$ profile from the DCP and SASW tests were normalized for effective confining stress and the cyclic resistance ratio for a $\mathrm{M} 7.5$ event $\left(\mathrm{CRR}_{\mathrm{M} 7.5}\right)$ computed following Youd et al. [14]. Figure 22 provides a comparison of the computed ground motion severity in terms of the cyclic stress ratio $\left(\mathrm{CSR}_{\mathrm{M} 7.5}\right)$ for both the Darfield and Christchurch earthquakes and $\mathrm{CRR}_{\mathrm{M} 7.5}$ for a test site in the eastern Christchurch suburb of Bexley. As shown in this figure, liquefaction is predicted to have occurred during both earthquakes (i.e., $\mathrm{CSR}_{\mathrm{M} 7.5}>\mathrm{CRR}_{\mathrm{M} 7.5}$ ). However, the factor of safety against liquefaction (FS) is lower for the Christchurch earthquake than the Darfield earthquake; where FS = $\mathrm{CRR}_{\mathrm{M} 7.5} / \mathrm{CSR}_{\mathrm{M} 7.5}$. The lower factor of safety indicates increased severity of liquefaction. These predictions are consistent with field observations in Bexley made after the two earthquakes.

Figure 23 illustrates the resulting data at all of the sites where DCP and SASW tests were performed following both the 4 September 2010 and 22 February 2011 earthquakes, based on the normalised and convert SPT N-value $\left(\mathrm{N}_{1,60 \mathrm{cs}}\right)$ and $\mathrm{CSR}_{\mathrm{M} 7.5}$ of the liquefaction-susceptible layer, as well as the surface evidence of liquefaction. For comparison, the liquefaction triggering relationship proposed for clean sand by Youd et al. [14] is also shown, for which it can be seen there is a good correlation with the obtained field data. 

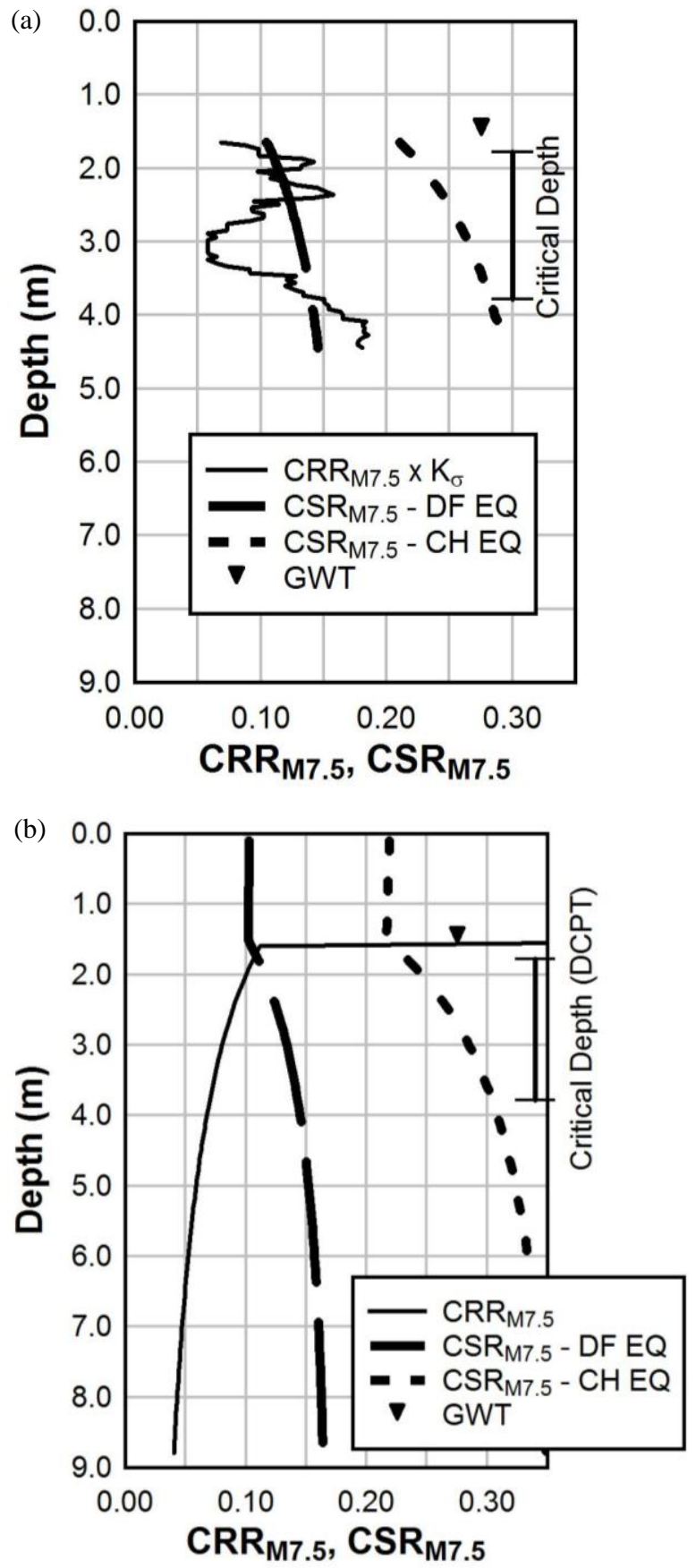

Figure 22: Comparison of $\mathrm{CSR}_{M 7.5}$ for the Darfield (DF EQ) and Christchurch (CH EQ) earthquakes with $C R R_{M 7.5}$ for a site in Bexley $(F C=9 \%):(a)$ profiles for DCP test; and (b) profiles for SASW test [13].

\section{Lateral spreading}

Along the Avon River, particularly to the east of CBD, lateral spreading occurred, causing horizontal displacements at the river bank on the order of several tens of centimeters to more than two meters (Figure 24). At ten locations along the Avon River, where lateral spreading measurements were conducted after the 4 September earthquake, measurements of lateral spreading displacements were carried out again after the February earthquake. It was found that the permanent lateral displacements were two to three times the displacement measured after the September earthquake indicating increased spreading movement which is in agreement with the more severe liquefaction observed in these areas during the February event. Ground surveying indicated that ground cracks associated with lateral spreading extended as far as (a)

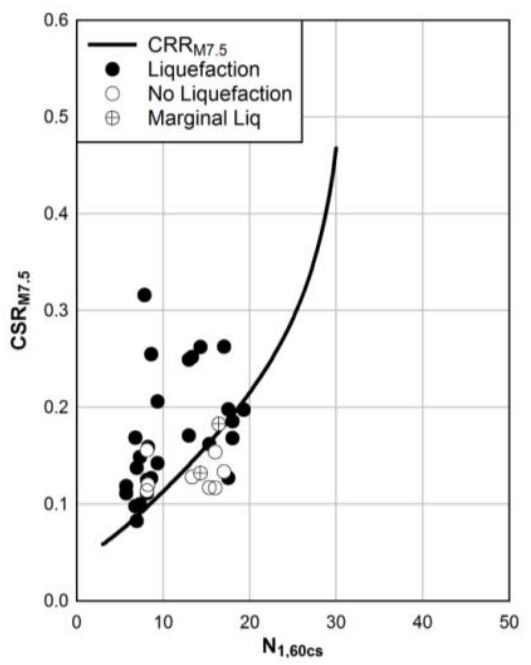

(b)

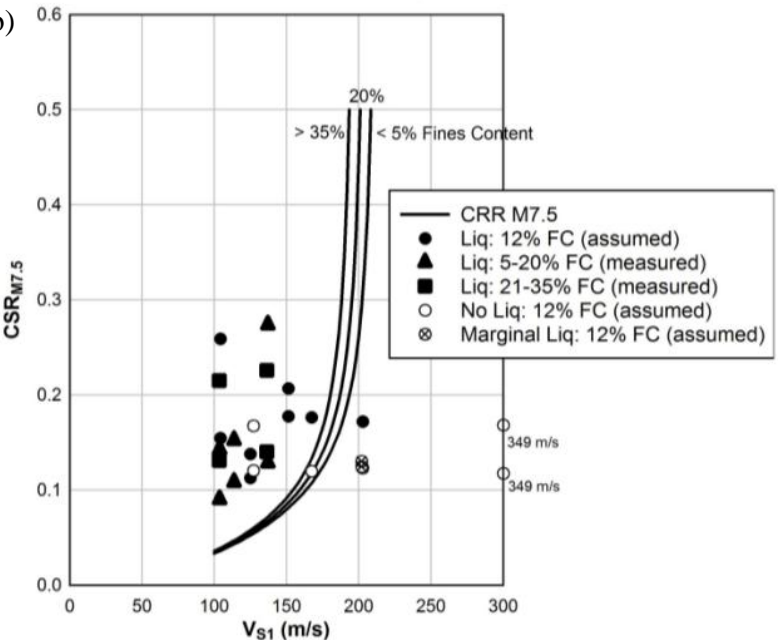

Figure 23: Summary of the: (a) DCP tests; and (b) SASW tests at all sites illustrating the computed cyclic stress ratio $\left(C_{C S R_{M 7.5}}\right)$ of the inferred liquefiable layer as well as whether surface manifestation of liquefaction was evident. Test data includes both the $4^{\text {th }}$ September 2010 and $22^{\text {nd }}$ February 2011 earthquakes [13].

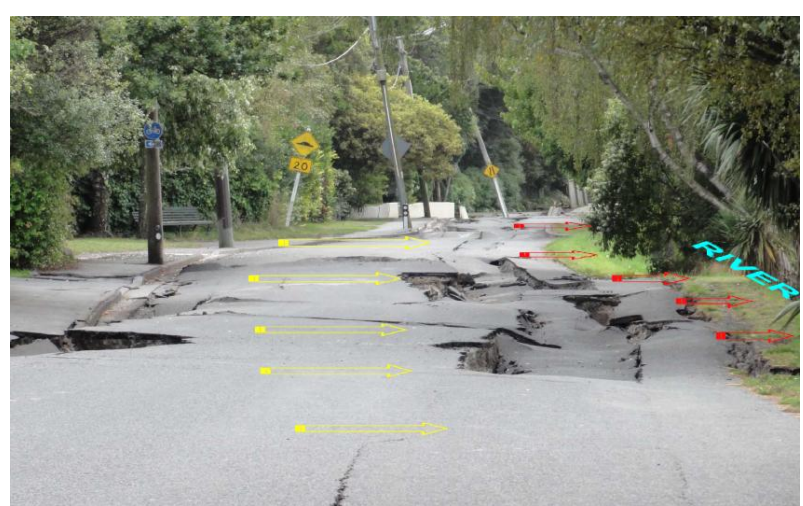

Figure 24: Lateral spreading toward the Avon River.

100-200 meters from the river, while other aerial observation methods suggest that the effects of spreading might have been even beyond these distances. Further more detailed evaluation/analysis of permanent ground displacements is currently in progress.

\section{Avon River temporary stop banks}

The significant subsidence of large areas of Christchurch as a result of the widespread liquefaction and associated lateral spreading increased the risk of flooding from both tidal and 
local rainfall events in areas of the city mostly coinciding with the residential red zone. In some areas, settlements of over a 1 metre were measured, a significant drop in ground elevation given the low lying nature of the city, even prior to the Darfield earthquake.

Emergency stop banks were initially constructed due to the expected spring tides in April 2011. These were built up to 1.8 $\mathrm{m}$ above mean sea level (MSL), with $11 \mathrm{~km}$ of stop banks built over four days along the Avon River. Silty gravel was used for the construction material, as it was readily available and reasonably impermeable. Lateral spreading cracks were filled prior to stop bank construction, but otherwise there were no improvements to the foundation material. An example of the stop bank construction along the Bexley Wetland is shown in Figure 25a, with a geogrid used under stop banks if the foundation material was weak. Large settlements in this area meant that many houses that were approximately a metre above the water level now sit below the crest of the stop banks (Figure 25b). Overall this emergency system performed well during the spring tides.
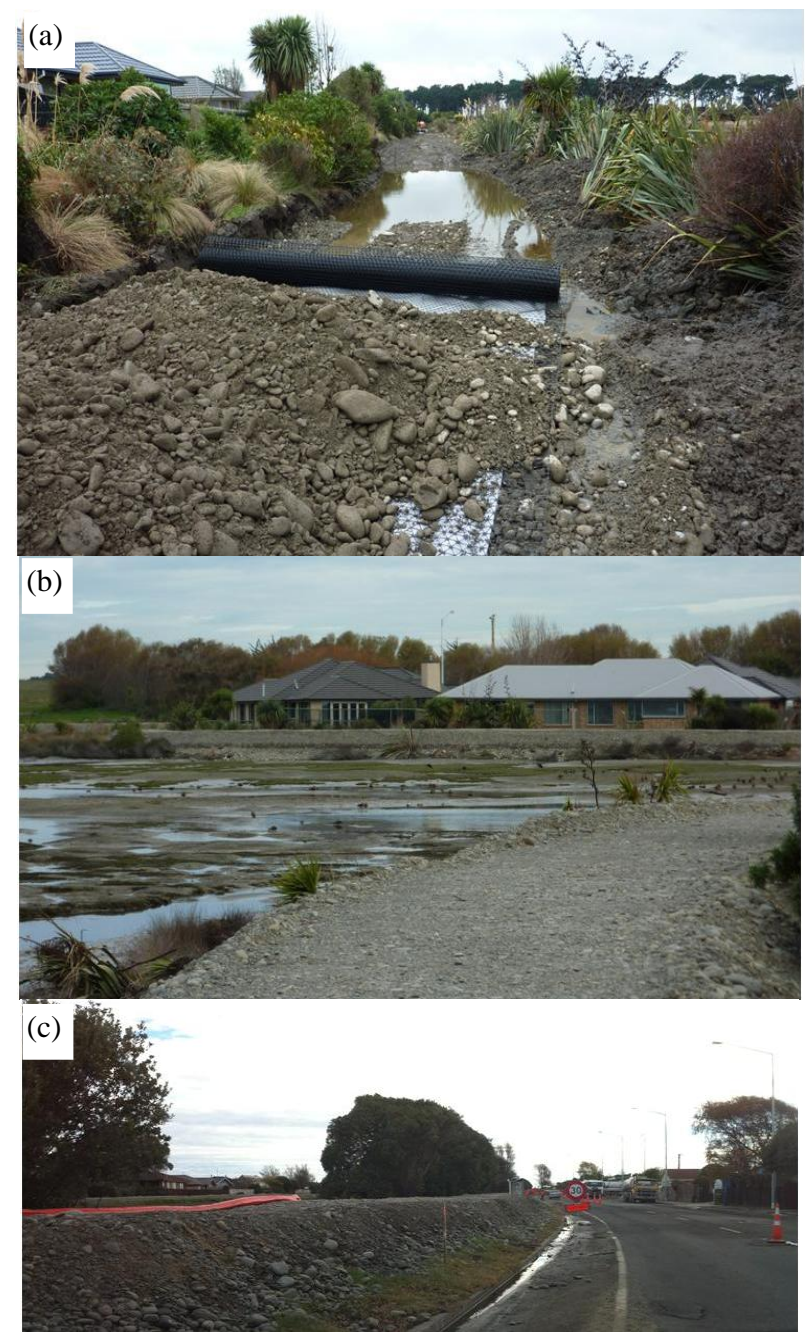

Figure 25: (a) Fill material used for construction and geogrid/liner for temporary stop banks; (b) position of residences below temporary stop banks in Bexley wetland; and (c) stop bank construction along New Brighton Rd.

Following the construction of emergency stop banks, a more comprehensive, but still temporary, stop bank network was constructed along the Avon River. A total of $17 \mathrm{~km}$ of stop banks were constructed from the mouth of the Avon River, upstream to the suburb of Avonside. Where space was available, a trapezoidal stop bank cross section with $3: 1$ or $4: 1$ horizontal to vertical slope, and a $2.5 \mathrm{~m}$ crest was used. In areas with limited space, reinforced earth and diamond block walls were used. An example of stop bank construction in Figure 25c shows the height of the stop banks relative to the roadway. Flood levels along the Avon River are approximately $3 \mathrm{~m}$ above MSL, meaning that stop banks with crests $1.4 \mathrm{~m}$ above the current ground levels would be required in places. Hence, seawalls and treatment of the foundation soils may be required to provide adequate flood protection in the medium to long term.

\section{LIQUEFACTION EFFECTS ON INFRASTRUCTURE}

\section{Bridge structures}

The city of Christchurch and the surrounding districts contain over 800 road, rail and pedestrian bridges. Most bridges are reinforced concrete, symmetric, and have small to moderate spans $(15-25 \mathrm{~m})$. Even though bridges were subjected to ground motions at or above their design levels throughout the central and eastern city, the majority sustained minimal damage as a result of inertial loading from shaking alone. The majority of bridge damage during the Christchurch earthquake was a result of kinematic loads imposed by lateral spreading of river banks along the Avon and Heathcote Rivers. Bridges along these rivers suffered varying levels of lateral spreadinginduced damage, with ground conditions and distance from the fault rupture controlling this response. Most of the bridge damage was located in the central and eastern parts of the city, where ground shaking was the strongest and soil conditions weakest. Although liquefaction was widespread, only five bridges within the city suffered major damage and ten developed moderate damage. This compares to only two bridges with moderate damage in the city following the Darfield earthquake. All bridges affected by lateral spreading were open to traffic within a week of the Christchurch earthquake. Only four bridges in the city had appreciable damage on sites that did not experience liquefaction, two with major damage, and two with moderate damage. A more complete summary of the bridge damage can be found in Wotherspoon et al. [15] and Palermo et al. [16].

The majority of the significant bridge damage occurred along the Avon River downstream of the Christchurch CBD. Of the nine bridges along this stretch of river, two had major damage and five were moderately damaged. The remaining two had only minor approach damage. The damage patterns along the Avon were fairly consistent: settlement and lateral spreading of approaches, back rotation and cracking of the abutments, and pier damage [15]. In most cases the bridge decks restrained the movement of the top of the abutment, resulting in their back rotation (e.g., Figure 26a). Some of the damaged bridges had pile foundations, with lateral spreading placing large demands on the abutment piles, and likely resulting in plastic hinging below grade. Settlement and spreading of the approaches impaired bridge serviceability, and was the main reason for bridge closure. The most severe case of settlement was the northern abutment of Gayhurst Rd Bridge, with large settlements of the surrounding area occurring after the Darfield, Christchurch, and June 132011 earthquakes. The combined effect of these events is clearly shown in Figure $26 \mathrm{~b}$, with over 1 metre of settlement. The southern abutment developed only minor settlements of the order of a few centimetres, highlighting the variability of damage from one bridge to another, but also at each individual site.

In the Christchurch CBD, bridges crossing the Avon River performed well, with only one of the 14 bridges in this area suffering moderate damage, 10 developing minor damage, and three experiencing no damage at all. All were single span bridges, with the most common damage being minor lateral spreading, compression or slight slumping of approach material, and minor cracking in abutments. Colombo St 
(a)
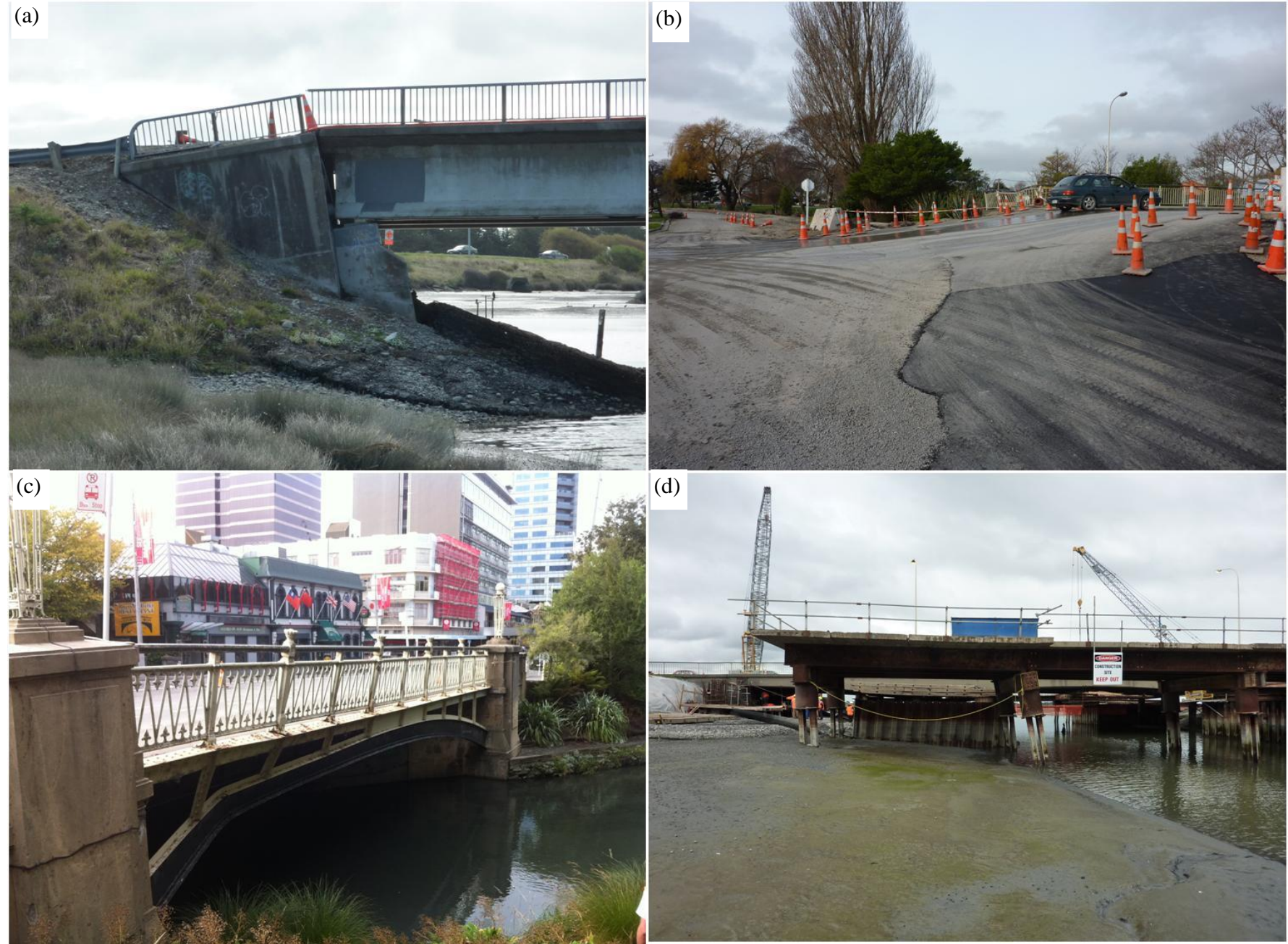

Figure 26: Summary of bridge damage: (a) back-rotation and settlement of the western abutment of South Brighton bridge; (b) settlement of the northern approach of Gayhurst Road bridge following the June 132011 earthquake; (c) abutment back-rotation and buckling of the steel arches of Colombo Street bridge; and (d) movement of temporary construction platform for Ferrymead bridge due to lateral spreading.

Bridge was one of the few bridges in the CBD to develop noticeable back-rotation of its abutments, being also one of the only bridges in the city with shallow foundations. This backrotation resulted in the buckling of the arched steel girders and handrails at the edge of the bridge, as shown in Figure 26c.

Of the 14 bridges along the Heathcote River, one had major damage, two were moderately damaged, and the remainder were either undamaged or suffered minor approach damage, despite being near the fault rupture. This lack of damage is inferred as a result of soils in this region having larger resistance to liquefaction and lateral spreading than those in the vicinity of the Avon River. The most severely damaged bridge was the Ferrymead Bridge, at the mouth of the Heathcote River and entrance of the Avon-Heathcote Estuary. This structure was undergoing a deck widening upgrade at the time of the Christchurch earthquake, with the original structure, partially completed upgrade, and the temporary construction platforms all damaged by lateral spreading of the river banks (Figure 26d).

\section{Flood stop banks}

In addition to liquefaction and lateral spreading along the Avon River and, to a much lesser extent, Heathcote River flowing through Christchurch, liquefaction also impacted the stop banks along the eastern extent of the Waimakariri and Kaiapoi rivers to the north [17].

Stop banks in the Canterbury region were often constructed by pushing up river gravels and silts. A typical cross section is

made up of a gravel core with 1-m thick silt cap, which extends from the river side and across the top, as shown in Figure $27 \mathrm{a}$. The stop banks typically sit on sandy soils at or near the ground water level. A toe filter was also constructed on the land side of the levee to prevent piping of sand during a high water event. The majority of the damage to stop banks during the Christchurch earthquake was a consequence of liquefaction in the foundation soils that resulted in lateral spreading, slumping, and/or settlement. As illustrated in Figure 27b, longitudinal cracks were observed along the crest of the stop banks. Although not desirable, moderate longitudinal crack widths are not as critical to the functionality of the stop banks as transverse cracks because they do not provide a direct seepage path through the stop bank. However, there is the potential for such longitudinal cracks to connect undetected transverse cracks or flaws that only penetrate partway through opposite sides of the stop bank. The resulting seepage path could potentially rapidly enlarge due to internal erosion and piping at high river levels.

Transverse cracks in the stop banks were less commonly observed than longitudinal cracks and were often associated with sharp bends along the length of the stop banks and/or slumping of the embankment. Because these cracks provide a direct seepage path from one side of the stop bank to the other, they can severely impact the functionality of the stop banks. Even transverse cracks having minor widths could potentially rapidly enlarge due to internal erosion and piping at high river levels and lead to the failure of that section of the stop bank. 
Settlement of stop bank sections resulted from both postliquefaction consolidation in the foundation soils and bearing capacity failures due to the reduced strength of the liquefied foundation soil. In addition to the degradation of stop bank functionality due settlement-induced cracking associated with the settlement (similar to that discussed above), settlement also reduces the amount of freeboard at high river levels. The significance of this loss depends on settlement magnitude, but in general it is not thought to be a significant issue with the stop bank system.
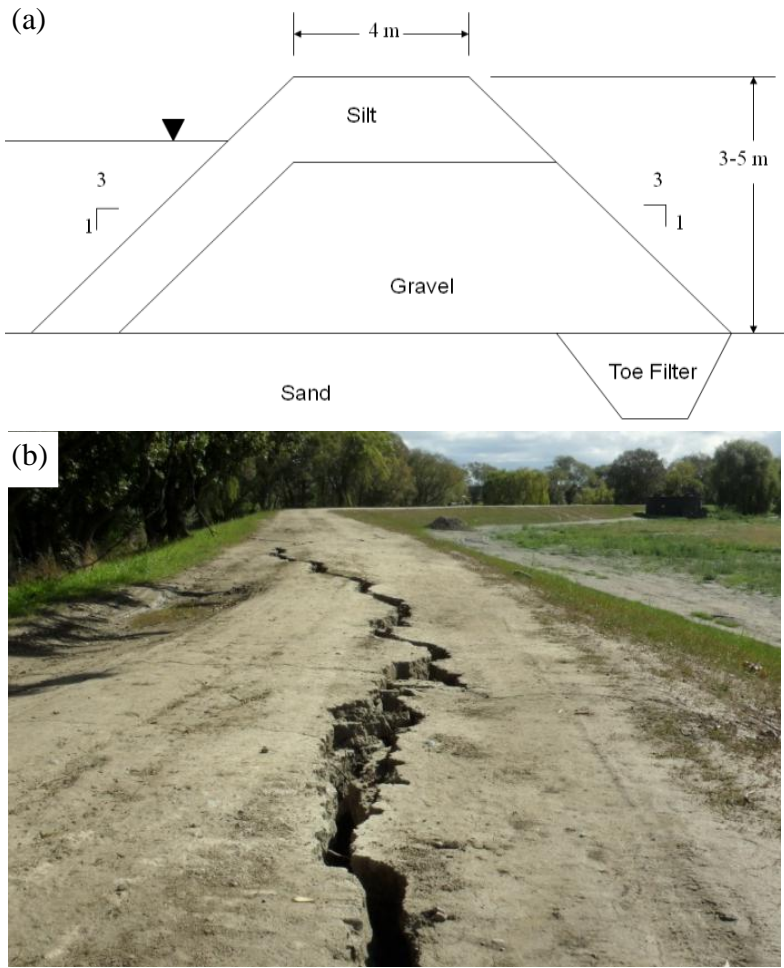

Figure 27: (a) Typical geometry and soil composition of stop bank cross section; and (b) typical longitudinal cracks running along the crest [17].

The majority of stop bank damage from the Christchurch earthquake occurred east of State Highway 1 (SH1) as shown in Figure 28. In this figure, damage severity is categorized using the scale given in Table 2. The scale has five grades that range from No Damage to Severe Damage. The damage patterns shown in Figure 28 are very similar to those from the Darfield earthquake, but are in general less severe for the Christchurch earthquake. The principal reason for this is that the ground motion severity is inferred to be less for the Christchurch earthquake than the Darfield earthquake in this

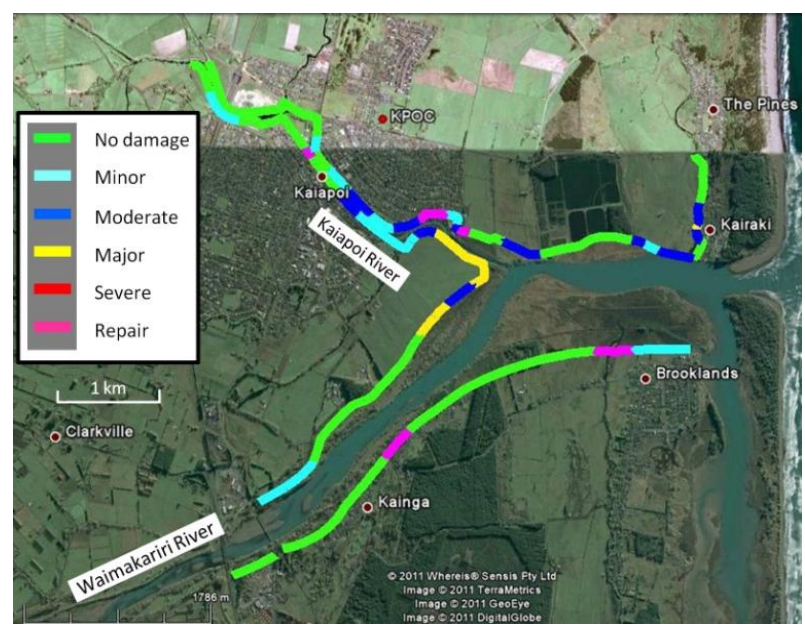

Figure 28: Observed damage to stop banks following the Christchurch earthquake [20], [19] area (e.g. PGA's of 0.33 and $0.21 \mathrm{~g}$ were recorded at the nearby Kaiapoi seismograph in these respective events). Note that some portions of the stop banks were already under repair by the time of the authors reconnaissance inspection following the Christchurch earthquake. In these cases, the authors supplemented their field observations, to the extent possible, with both observations from high resolution aerial images taken the day after the Christchurch earthquake and field observations made by ECan consultants [18].

To examine the relationship between the severity of the induced damage to the stop banks and the liquefaction response of the foundation soil, a stretch of stop banks along the Kaiapoi River was examined in more depth. As shown in Figure 28, these stop banks sustained damage ranging from No Damage to Severe Damage (Table 2). Following the Darfield earthquake, the New Zealand Earthquake Commission (EQC) contracted a local firm to perform a series of cone penetration tests (CPT), among other in-situ tests, throughout North and South Kaiapoi [19].

From interpretation of CPT logs and available borehole data [19], the soil profile along the north bank of the Kaiapoi River east of the Williams Street Bridge is characterized by approximately $4 \mathrm{~m}$ of very loose to loose sand overlying approximately $4 \mathrm{~m}$ of loose to medium dense gravelly sand. Below approximately $8 \mathrm{~m}$, the sand and gravel layers tend to be significantly denser than the overlying layers. The depth to the ground water table varies, but is approximately $1.5 \mathrm{~m}$ deep. On the south bank of the Kaiapoi River east of the Williams Street Bridge, the soil profile is characterized by approximately $6 \mathrm{~m}$ of very loose to loose silty sand/sand overlying an approximately 2-m thick layer of loose to medium dense sand/gravelly sand. Samples of the liquefiable soils taken adjacent to the stop banks on the north bank had fines contents around $15 \%$, with the fines being non-plastic.

Using the CPT soundings, the liquefaction susceptibility of the foundation soils was analyzed following the procedures outlined in Youd et al. [14]. The horizontal PGA recorded at the strong motion seismograph station at Kaipoi (KPOC) was used for determining $\mathrm{CSR}_{\mathrm{M} 7.5}$, with PGAs of 0.33 and $0.21 \mathrm{~g}$ for the Darfield and Christchurch events, respectively. Figure 29 shows the results from the liquefaction evaluation for the two representative CPT soundings mentioned above. In these figures, the cyclic resistance ratio (CRR) for each profile and the CSRs for both events are plotted together, where both the CRR and CSR are adjusted to a $\mathrm{M}_{\mathrm{w}} 7.5$ earthquake. For liquefiable soils (i.e., gravels, sands and cohesionless silts), liquefaction is predicted to have occurred at depths where the $\mathrm{CSR}_{\mathrm{M} 7.5}>\mathrm{CRR}_{\mathrm{M} 7.5}$. Accordingly, for both profiles,

Table 2: Damage severity categories

\begin{tabular}{cc} 
Category & Description \\
\hline No Damage & No observed damage \\
Minor & $\begin{array}{c}\text { Cracks up to 5 mm wide and/or 300 } \\
\text { mm deep. Negligible settlement of } \\
\text { crest. }\end{array}$ \\
Mamage & Cracks up to 1 m deep. Some \\
Damage & settlement of crest. \\
Major & Cracks greater than 1 m deep. \\
Evidence of deep seated movement \\
and/or settlement.
\end{tabular}


(a)

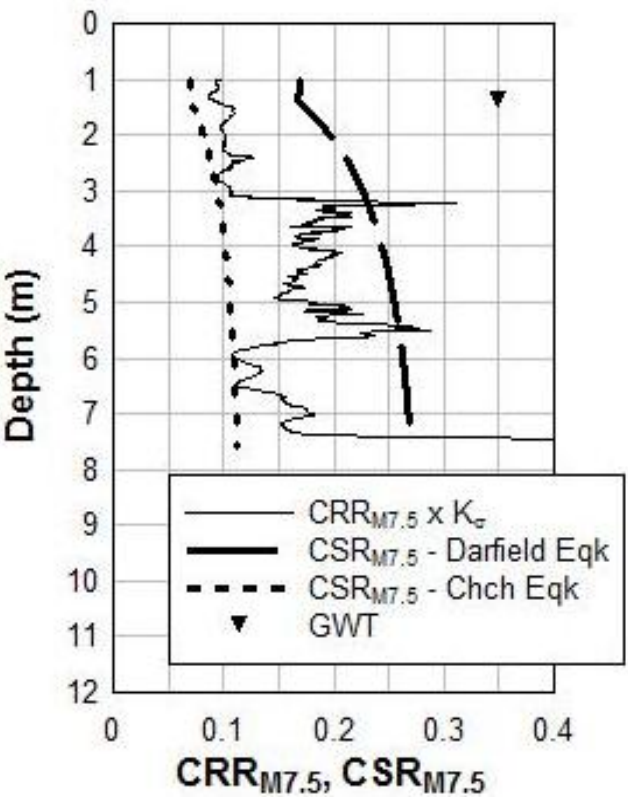

(b)

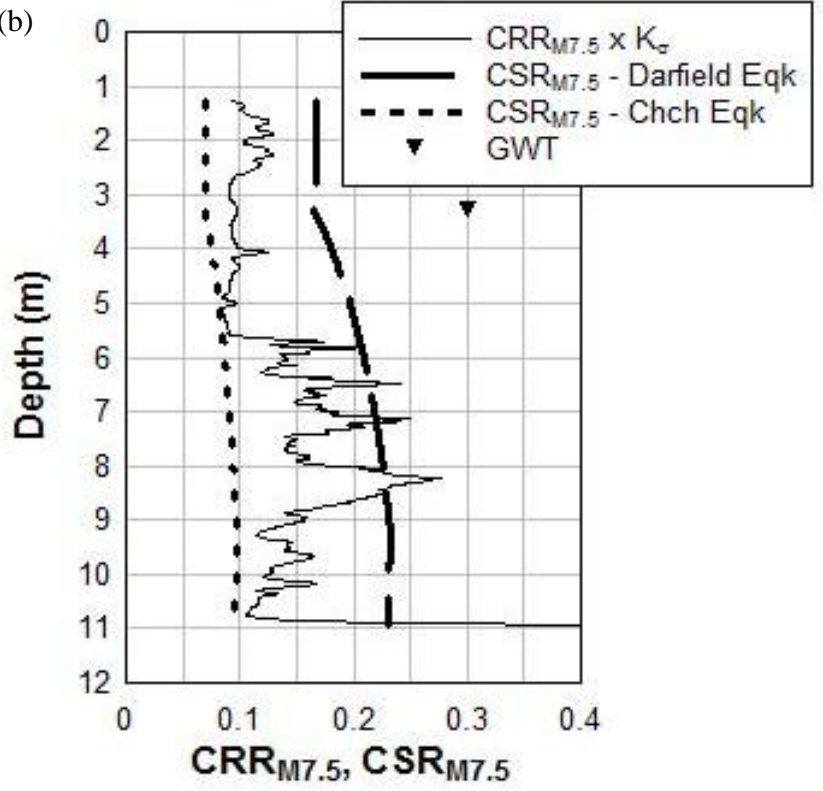

Figure 29: Liquefaction evaluation for representative sites on the: (a) north bank; and (b) south stopbank of the Kaiapoi river in the Darfield and Christchurch earthquakes.

liquefaction is predicted to have occurred during the Darfield earthquake for almost the entire depth from the ground water table to the top of the dense gravel/sand layer (i.e., to $\sim 7.5 \mathrm{~m}$ and $\sim 11 \mathrm{~m}$ for the north and south river banks, respectively). However, during the Christchurch earthquake, marginal liquefaction is predicted to occur at a few isolated depths within both profiles.

\section{Impacts of liquefaction on pipe networks}

The large ground movements and deformation (in extension, compression, shear, and combined modes) including ground distortion, cracks, fissures and venting sink-holes, resulting from the severe liquefaction and lateral spreading caused severe damage to underground pipe networks such as the potable water, wastewater and storm water systems. These systems have different characteristics and they were affected and performed quite differently in the 22 February earthquake.

The potable water system is a system of relatively shallow pipe network (mostly in the top $60 \mathrm{~cm}$ of the ground). It is a pressurized system composed of mains and sub-mains. Figure 30 shows a summary of the water mains network in Christchurch indicating pipe materials (solid lines) and the location of breaks (faults; red solid symbols) caused by the 22 February earthquake. Superimposed in this figure is the liquefaction map (shown in Figure 4) indicating the areas affected with different severity of liquefaction. It is apparent in this figure that most of the breaks were located in the area affected by liquefaction. A more rigorous preliminary analysis indicates that about $4.6 \%$ of the pipes (pipe segments) were damaged, or about $78 \mathrm{~km}$ out of $1676 \mathrm{~km}$ total pipe length. About $80 \%$ of the damaged pipes were in areas that manifested either moderate-to-severe or low-to-moderate liquefaction. Similar observations and preliminary findings were obtained for the sub-mains system which is dominated by polyethylene (PE) pipes. Despite the relatively large number of breaks, the potable water supply was quickly restored within several days of the earthquake.

The waste water system was hit particularly hard in the areas severely affected by liquefaction and lateral spreading. Out of the $1766 \mathrm{~km}$ long waste water network, $142 \mathrm{~km} \mathrm{(8 \% )} \mathrm{were} \mathrm{out}$ of service; and $542 \mathrm{~km}(31 \%)$ with limited service on 16 March 2011 (i.e. three weeks after the February earthquake), as shown in Figure 31. A significant part of the network was still out of service even three months after the earthquake, and it is estimated that it will take two to three years to fully recover the system.

Loss of grade, joint failures, cracks in pipes and failure of laterals were the most commonly observed types of failures. Loss of critical facilities such as pump stations also contributed to the overall poor performance of the system. Buoyancy of concrete vaults at potable water and wastewater pump stations, compounded by liquefaction-induced settlement, caused pipeline breaks at their connections with the vaults. Approximately $1 \mathrm{~m}$ of settlement at the Bexley Pump Station ruptured the well, flooding the surrounding neighborhood at $140 \mathrm{~m}^{3} / \mathrm{hr}$. Silt and sand from liquefaction washed into the Bromley sewage treatment plant from broken wastewater pipelines, causing damage in the primary settling tanks. Nearly all facilities at the sewage treatment plant were affected by liquefaction, which caused differential settlement of the clarifiers, thereby seriously impairing secondary treatment capabilities.

Note that the waste water system includes both pressurised and gravity components, and the network consists of pipes of different sizes and materials including concrete, ceramic, cast iron and plastic (PVC and PE) pipes. This system is much deeper, typically at 3-4 $\mathrm{m}$ depth from the ground surface, making it more vulnerable to liquefaction effects. For both potable water and waste water systems, the most severe damage was inflicted by lateral spreading.

\section{Impact on electrical infrastructure}

There was serious damage to the underground electric power system, with failure of all major $66 \mathrm{kV}$ underground cables supplying the Dallington and Brighton areas caused by liquefaction-induced ground movements. Over $50 \%$ of all 66 $\mathrm{kV}$ cables suffered damage at multiple locations. 


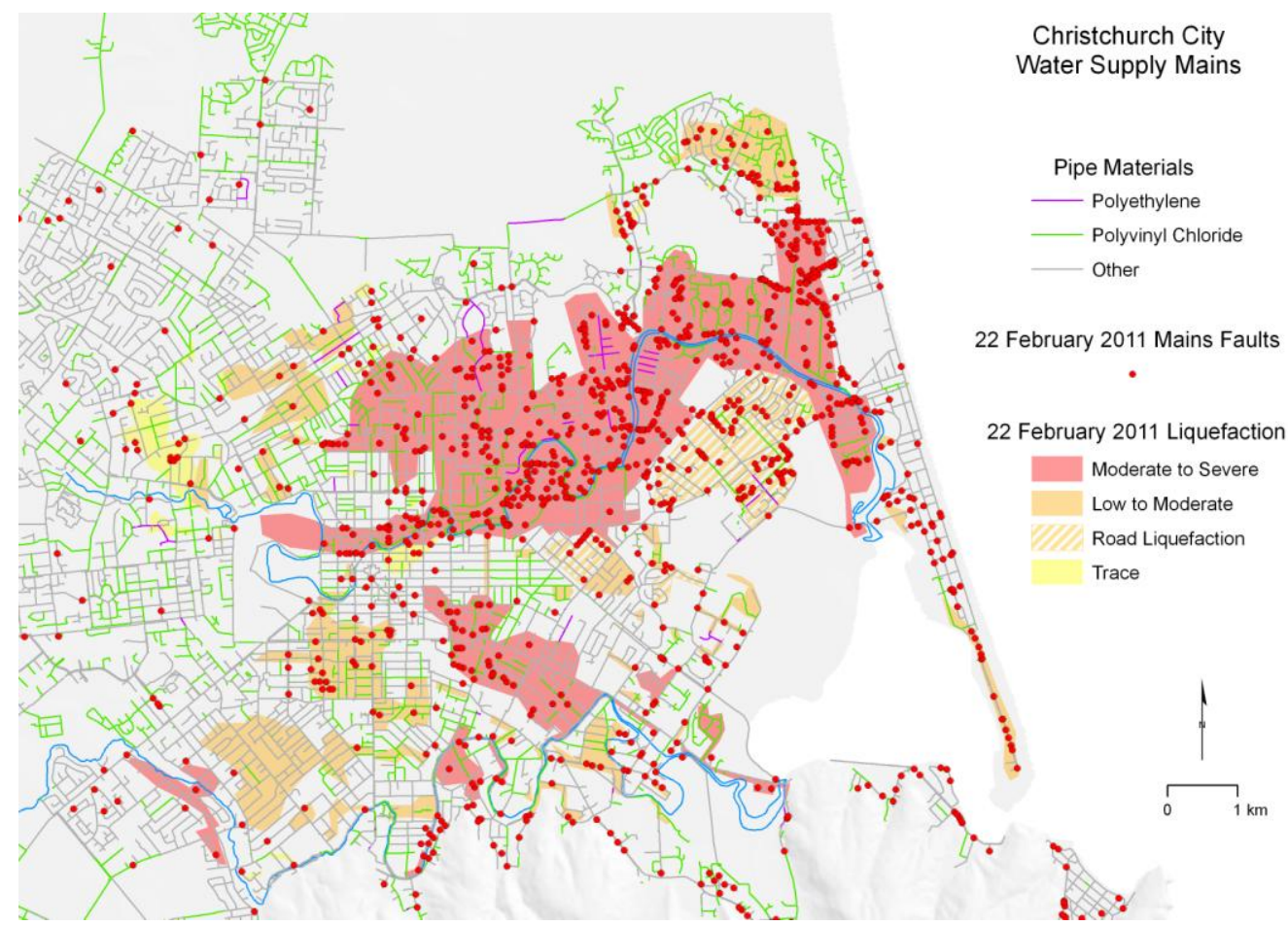

Figure 30: Water mains pipe network and location of breaks (faults) caused by the 22 February 2011 earthquake; coloured lines indicate pipe materials; coloured areas indicate liquefaction severity as defined and mapped in Figure 4.

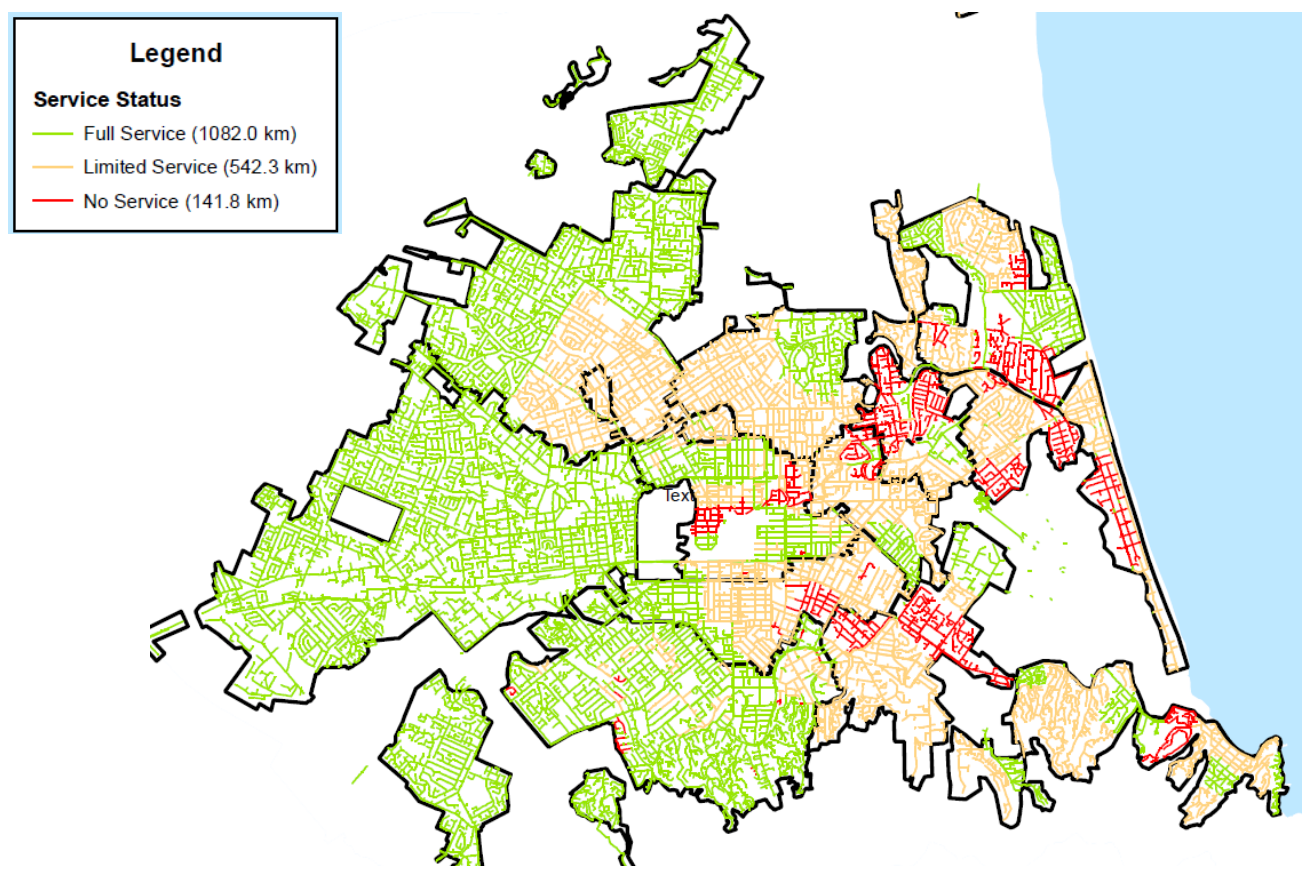

Figure 31: Waste water service status on 16 March 2011. (M. Christison, pers. comm.)

\section{PERFORMANCE OF IMPROVED GROUND}

\section{Waterside Apartment Building}

The Waterside apartment building area was investigated in detail with regard to the performance of improved ground to resist liquefaction. The building is indicated by the dashed white line in Figure 32a, is situated between the AvonHeathcote estuary to the north and Ferry Rd to the south, and immediately west of the Ferrymead Bridge. As shown in Figure $32 \mathrm{~b}$, the structure consists of a 6 -story precast concrete panel building with a single basement level carpark. The building is supported on shallow foundations overlying stone columns. Large volumes of ejecta were evident in the unimproved areas surrounding the structure, with sand boils still present in the estuary adjacent to the structure. Two lateral spread cracks were noted on the north side of the building between the water and the building. The crack closest to the water had a maximum width of $13 \mathrm{~cm}$ and the crack closest to the building had a maximum width of about $4 \mathrm{~cm}$. The larger crack extended along the top of the embankment north of Tidal View Rd, and additional cracking was present between the road and building.

There was evidence of movement of the building following the Christchurch earthquake, however these were relatively minor given the severity of liquefaction in the surrounding area. The building settled between 4 and $8 \mathrm{~cm}$ and had a slight tilt toward the water. On the north side of the building, separation walls on the ground surface showed differential movement as shown in Figure 32c. The separation walls sloped downward towards the building at an angle of about 0.4 to 0.5 degrees. This caused the caulk in the expansion joint to 

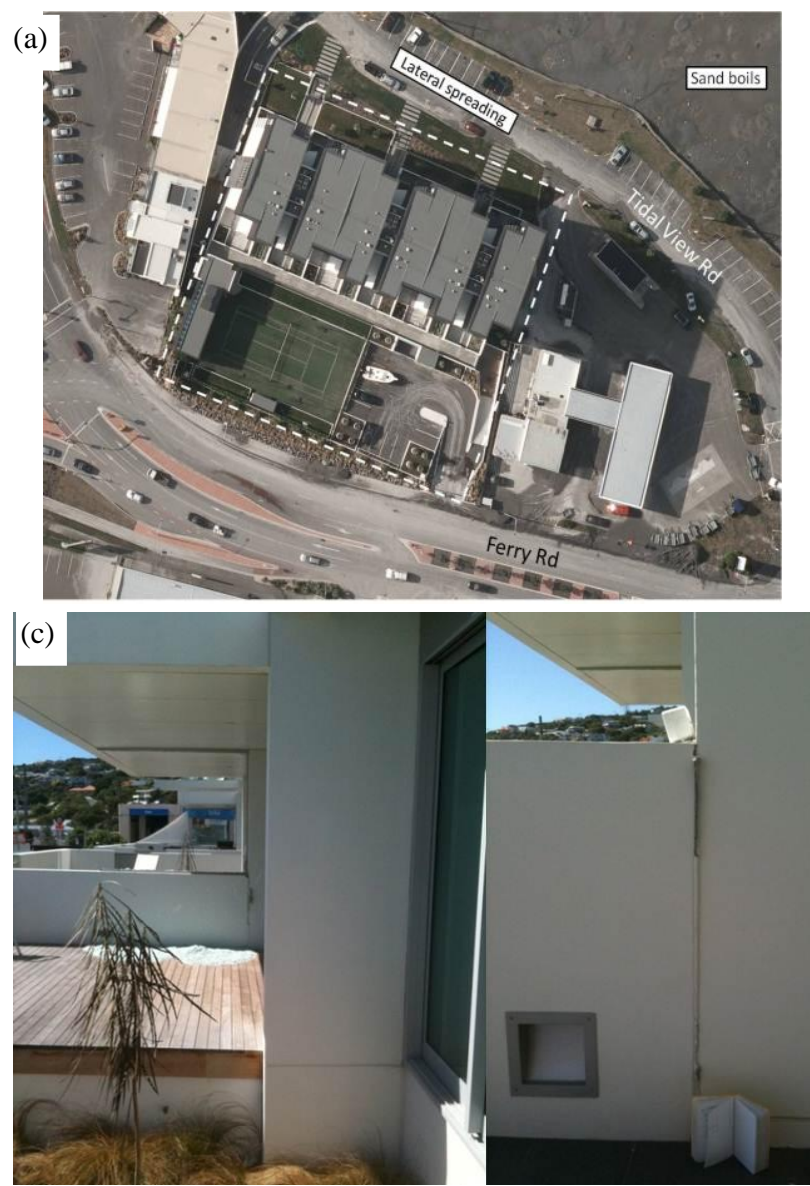

Figure 32: (a) Aerial view of Ferrymead apartment building indicating surrounding ejected material; and (b) south-west looking view of the apartments; (c) separation of walls on the north side of the building, including sloping of the separation walls and shattered glass panels, and compression of caulk at top of expansion joint; and (d) the basement parking garage. Note the high water mark on the walls.

be compressed at the top of the wall. Three of the glass panels that were mounted on top of the separation walls were shattered, likely due to the compression of the glass against the deck above, and cracking of the wall connection beneath this was also evident. The separation walls on the south side of the building also sloped downward toward the building at an angle of about 0.8 degrees. Cracking along concrete walkways extending out from the structure also indicated differential settlement of the building relative to the ground to the north. Significant flooding was observed in the basement as shown in Figure 32d, and sand had flowed up through the drains in the basement slab. In the absence of ground improvement, this structure would most likely have suffered much more significant damage.

\section{AMI Stadium}

AMI Stadium is located in an area that experienced extensive liquefaction and ground damage, with the ejected material within and surrounding the stadium shown in Figure 33a. All four stands suffered varying levels of damage during the earthquake, and all were founded on shallow foundations. The Hadlee Stand had no ground improvement measures, suffered severe structural damage and has been recommended for demolition. The Tui Stand was constructed on a fill platform to raise its level, and suffered less severe structural damage during the earthquake.

Both the Paul Kelly and Deans Stands were constructed on widely-spaced stone columns installed within their footprint. The Deans Stand has shallow foundations connected by grade beams built upon $8 \mathrm{~m}$ deep stone columns, while the Paul Kelly Stand has a slab foundation up to a metre thick founded on $9 \mathrm{~m}$ deep stone columns. The stone columns beneath the
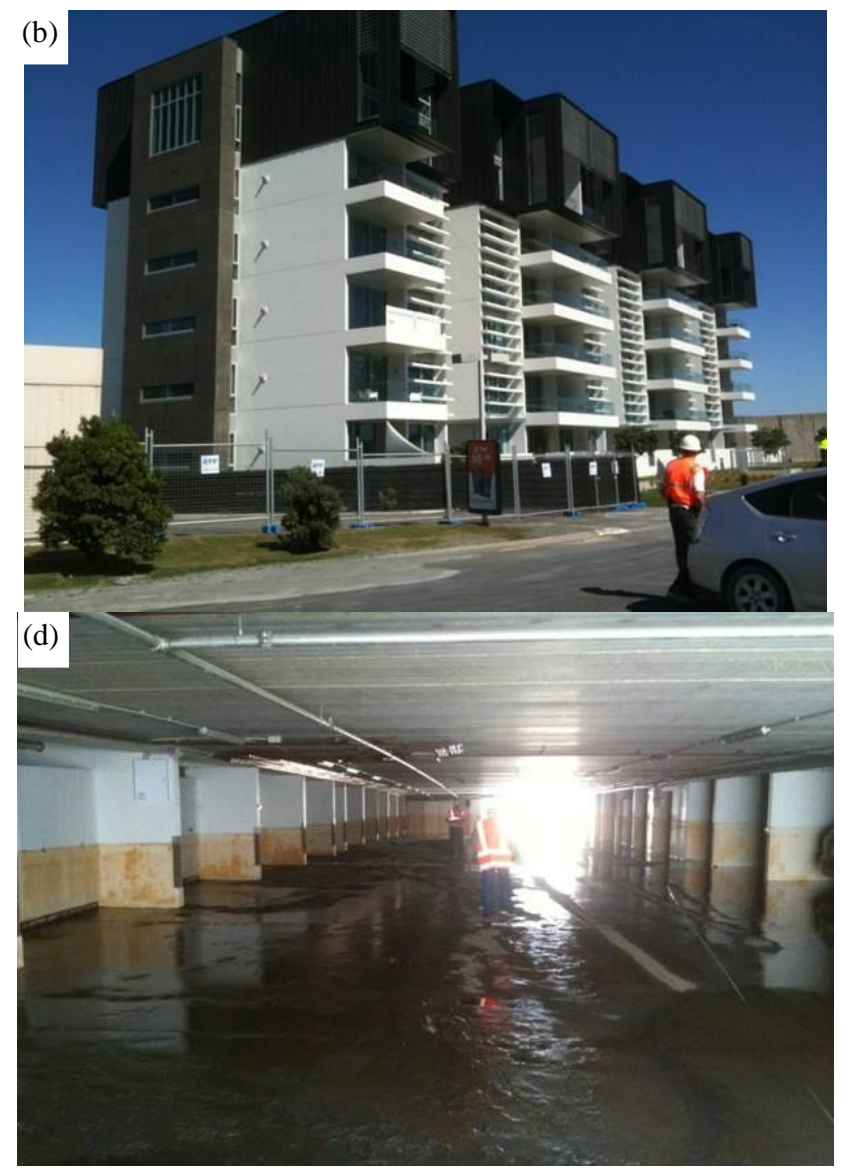


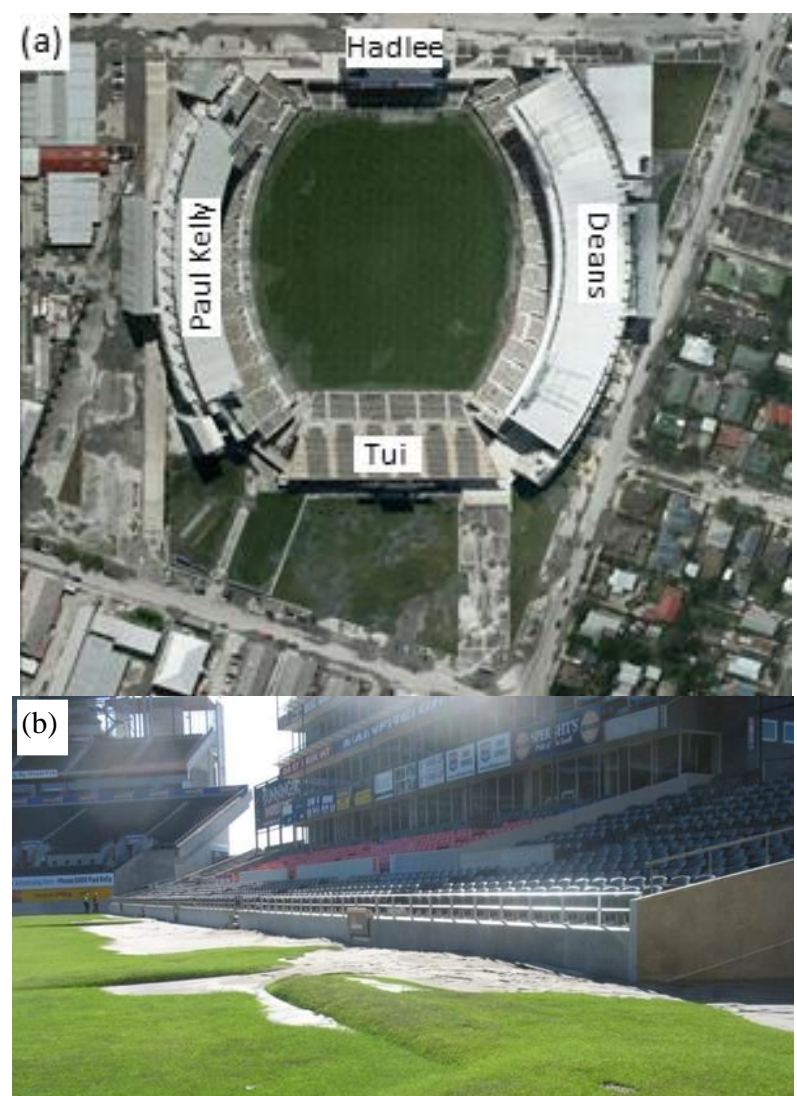

Figure 33: (a) Aerial photo of AMI Stadium indicating liquefaction damage; and (b) Liquefaction damage to the stadium field.

\section{SLOPE INSTABILITY IN THE PORT HILLS}

Rock falls, block failures, and other forms of landslides were widespread in the near-fault region around the Port Hills (Sumner, Redcliffs, Lyttelton, Cass Bay, and Rapaki). Landslides were significant on the northern side of Lyttelton Harbour, with relatively less rock falls on the southern side of the Harbour (e.g. Diamond Harbour). These slope failures resulted in five deaths and damaged or destroyed many roads, tracks, and structures. Almost every cliff face in the Port Hills generated a rock fall, while over-steepened road cuts and quarry walls were subjected to block collapse or large volumes of rock fall. Rock falls were the most widespread manifestation of slope failure, causing the five deaths and the most structural damage. Deep-seated landslides were found only at a few locations, most of which were at the top of coastal headlands. Numerous failures occurred in retaining walls and fill slopes, resulting in damage to roads, property, and commercial and residential structures.

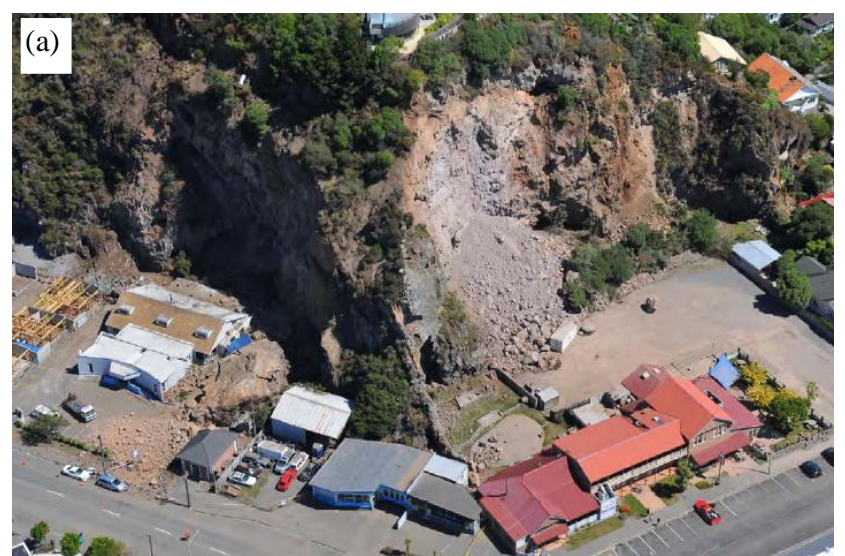

Both natural and modified (quarry) volcanic rock faces were sources of rock fall and block collapse, forming large talus slopes at the base of cliffs, or rock fall run out on some slopes. The volcanic rocks exposed across the northern part of the Banks Peninsula are part of the Lyttelton Volcanic Group, and include dominantly basaltic to trachytic lava flows interbedded with breccia and tuff, and lava domes. More than 20 residential and commercial buildings downslope of the cliffs in Redcliffs and Sumner were destroyed by rock fall debris (e.g., Figure 34).

Several types of rock fall protective measures were observed at the base of the quarry wall in the Redcliffs. These included a gabion, rock fall fences, and a rock berm. The gabion performed well in stopping the block collapse of the cliff from impacting the house below the gabion. Two rock fall fences adjacent to the gabion were less successful, as both were filled and overtopped by the large volume of the block failures. A rock berm was constructed along the schoolyard border at the base of the quarry wall, possibly using debris from a more limited rock fall that may have been generated by the 2010 Darfield earthquake (the berm is not present on the 2009 preearthquake imagery). This berm was successful in protecting the schoolyard, as no rocks were observed in the area beyond the rock berm.

\section{CONCLUSIONS}

This manuscript has provided documentation of some of the salient geotechnical features of the 22 February 2011 earthquake, as evident during extensive post-event reconnaissance. The geotechnical aspects of this earthquake are exceptional from several viewpoints. The earthquakeinduced ground shaking caused very widespread and severe liquefaction in native soils of Christchurch (including its central business district), and numerous rock falls and slope failures in the Port Hills, all of which resulted in fatalities, huge damage to the city infrastructure and/or large economic losses. Tens of thousands residential properties were profoundly affected by the liquefaction and rock/slope instabilities; the central business district still remains cordoned off for general use (at the time of writing), with at least one third of its building stock going to be demolished; and the lifelines of Christchurch suffered extensive damage. The 22 February 2011 earthquake was the second strong earthquake to hit Christchurch in a period of less than six months, and was subsequently followed by a two other notable strong earthquakes on 13 June 2011. The observations of reliquefaction and cumulative effects from this series of strong earthquakes are also unprecedented. More in-depth studies on the phenomena and damage features presented herein are currently under way, with the hope to advance the research findings in this area and provide strong support to the rebuild and recovery of Christchurch.

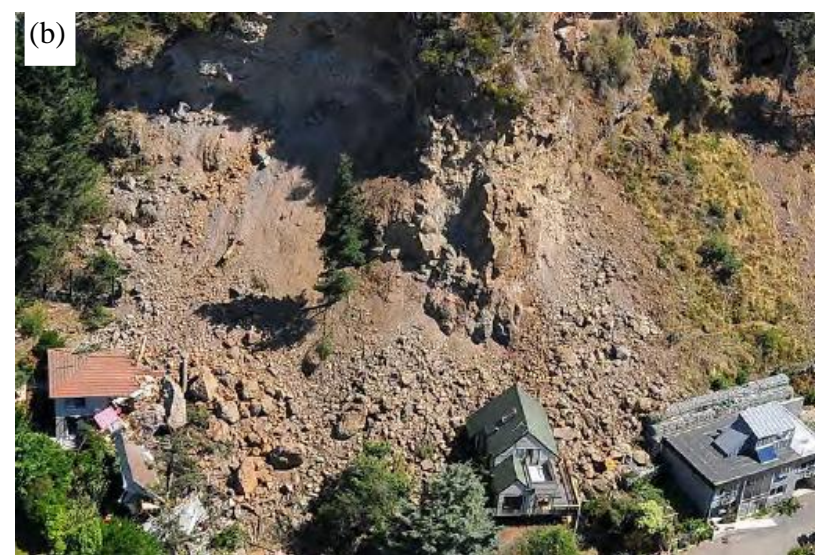

Figure 34: Examples of rock falls on the Ports hills. 


\section{ACKNOWLEDGEMENTS}

The primary support in the reconnaissance effort for the NZ members was provided by the Earthquake Commission New Zealand (EQC) and University of Canterbury. Liam Wotherspoon's position at the University of Auckland is funded by the Earthquake Commission. The primary support for the US GEER Team members was provided by grants from the U.S. National Science Foundation (NSF) as part of the Geo-engineering Extreme Event Reconnaissance (GEER) Association activity through CMMI-00323914 and CMMI1137977. Rod Cameron and Mark Christison, Christchurch City Council, provided invaluable information on the potable water and waste water systems. The first author would also like to acknowledge the funding support from the Natural Hazards Research Platform (NHRP) through the short-term recovery projects. Any opinions, findings, and conclusions or recommendations expressed in this material are those of the authors and do not necessarily reflect the views of the National Science Foundation, EQC, or the host institutions of the authors.

Finally, we would also like to acknowledge the assistance of all NZ and US GEER team members who participated in the reconnaissance of these events. Their contributions are noted at the GEER website at: http://www.geerassociation.org/.

\section{REFERENCES}

[1] NZSEE. (2010) "Special Issue: Preliminary observations of the 2010 Darfield (Canterbury) Earthquakes". Bulletin of the New Zealand Society for Earthquake Engineering; 43(4): 215-439.

[2] Gledhill, K., Ristau, J., Reyners, M., Fry, B. and Holden, C. (2011) "The Darfield (Canterbury, New Zealand) Mw 7.1 Earthquake of September 2010: A Preliminary Seismological Report". Seismological Research Letters; 82(3): 378-386.

[3] Stirling, M.W., Gerstenberger, M., Litchfield, N., McVerry, G.H., Smith, W.D., Pettinga, J.R. and Barnes, P. (2007) "Updated probabilistic seismic hazard assessment for the Canterbury region". 58.

[4] Beavan, J., Fielding, E.J., Motagh, M., Samsonov, S. and Donnelly, B.S. (2011) "Fault location and slip distribution of 22 February 2011 Mw 6.3 Christchurch, New Zealand, earthquake for geodetic data". Seismological Research Letters, Focused Issue on the 2011 Christchurch New Zealand Earthquake.

[5] Holden, C. (2011) "Kinematic source model of the February 22nd 2011 Mw6.3 Christchurch earthquake using strong motion data". Seismological Research Letters, Focused Issue on the 2011 Christchurch New Zealand Earthquake.

[6] Brown, L.J. and Weeber, J.H. (1992) "Geology of the Christchurch urban area", Geological and Nuclear Sciences 110.

[7] Cubrinovski, M., Bray, J.D., Taylor, M.L., Giorgini, S., Bradley, B.A., Wotherspoon, L. and Zupan, J. (2011) "Soil liquefaction effects in the Central Business District during the February 2011 Christchurch earthquake". Seismological Research Letters, Focused Issue on the 2011 Christchurch New Zealand Earthquake.

[8] Bradley, B.A. and Cubrinovski, M. (2011) "Near-source strong ground motions observed in the 22 Febraury 2011 Christchurch earthquake". Seismological Research Letters, Focused Issue on the 2011 Christchurch New Zealand Earthquake.
[9] NZS 1170.5. (2004) "Structural design actions, Part 5: Earthquake actions - New Zealand". Standards New Zealand: Wellington, New Zealand, 82.

[10] Cubrinovski, M. and Taylor, M. (2011) "Liquefaction map of Christchurch based on drivethrough reconnaissance after the 22 February 2011 earthquake". University of Canterbury.

[11] Elder, D. and McCahon, I. (1990) "Near surface groundwater hydrology and excavation dewatering in Christchurch", in Groundwater and Seepage Symposium: Auckland, New Zealand.

[12] Cubrinovski, M. and McCahon, I. (2011) "Foundations on deep alluvial soils", University of Canterbury, Christchurch. 40.

[13] Green, R.A., Wood, C., Cox, B., Cubrinovski, M., Wotherspoon, L., Bradley, B.A., Algie, T., Allen, J., Bradshaw, A. and Rix, G. (2011) "Use of DCP and SASW tests to evaluate liquefaction potential: Prediction vs. observations during the recent New Zealand earthquakes". Seismological Research Letters, Focused Issue on the 2011 Christchurch New Zealand Earthquake.

[14] Youd, T.L, Member C, ASCE, Idriss, I.M., Fellow C-C, Andrus, R.D., Arango, I., Castro, G., Christian, J.T., Dobry, R., Finn, W.D.L., Jr. LFH, Hynes, M.E., Ishihara, K., Koester, J.P., Liao, S.S.C., III WFM, Martin, G.R., Mitchell, J.K., Moriwaki, Y., Power, M.S., Robertson, P.K., Seed, R.B. and II KHS. (2001) "Liquefaction Resistance of Soils: Summary Report from the 1996 NCEER and 1998 NCEER/NSF Workshops on Evaluation of Liquefaction Resistance of Soils". Journal of Geotechnical and Geoenvironmental Engineering; 127(10): 817-833.

[15] Wotherspoon, L., Bradshaw, A., Green, A.G., Wood, C., Palmero, A., Cubrinovski, M. and Bradley, B.A. (2011) "Bridge performance during the 2011 Christchurch earthquake". Seismological Research Letters, Focused Issue on the 2011 Christchurch New Zealand Earthquake; 82(6): 950-964.

[16] Palmero, A. et al. (2011) "Bridge performance 22 Feb earthquake". Bulletin of the New Zealand Society for Earthquake Engineering.

[17] Green, R.A., Allen, J., Wotherspoon, L., Cubrinovski, M., Bradley, B., Bradshaw, A., Cox, B. and Algie, T. (2011) "Performance of Levees (Stopbanks) during the 4 september $2010 \mathrm{Mw} 7.1$ Darfield and 22 February $2011 \mathrm{Mw} 6.2$ Christchurch, New Zealand, Earthquakes". Seismological Research Letters; 82(6): 939-949.

[18] Riley Consultants. (2011) "Waimakariri and Kaiapoi River Stopbanks Findings of Condition Assessment Post 22 February 2011 Earthquake. Letter Report 10820/2-A from Riley Consultants to Environment Canterbury (ECan)": Christchurch, New Zealand.

[19] Tonkin and Taylor. (2011) "Darfield Earthquake Recovery Geotechnical Factual Report - Kaiapoi North", Tonkin and Taylor: Christchurch, NZ.

[20] Green, R.A., Allen, J., Wotherspoon, L., Cubrinovski, M., Bradley, B.A., Bradshaw, A., Cox, B. and Algie, T. (2011) "Performance of levees (Stopbanks) during the 4 September 2010 Mw7.0 Darfield and 22 February 2011 Mw6.1 Christchurch, New Zealand Earthquakes". Seismological Research Letters, Focused Issue on the 2011 Christchurch New Zealand Earthquake. 